\title{
Assessing L-Band GNSS-Reflectometry and Imaging Radar for Detecting Sub-Canopy Inundation Dynamics in a Tropical Wetlands Complex
}

\author{
Katherine Jensen ${ }^{1,2, *}$, Kyle McDonald ${ }^{1,2,3}{ }^{\text {, Erika Podest }}{ }^{3}$, Nereida Rodriguez-Alvarez ${ }^{3}$, \\ Viviana Horna ${ }^{4}$ and Nicholas Steiner ${ }^{1}$ \\ 1 Department of Earth and Atmospheric Science, The City College of New York, City University of New York, \\ New York, NY 10031, USA; kmcdonald2@ccny.cuny.edu (K.M.); nsteiner@ccny.cuny.edu (N.S.) \\ 2 Earth and Environmental Sciences Program, The Graduate Center, City University of New York, \\ New York, NY 10016, USA \\ 3 Jet Propulsion Laboratory, California Institute of Technology, Pasadena, CA 91109, USA; \\ erika.podest@jpl.nasa.gov (E.P.); nereida.rodriguez.alvarez@jpl.nasa.gov (N.R.-A.) \\ 4 Institute of Botany, University of Hohenheim, 70593 Stuttgart, Germany; viviana.horna@gmx.net \\ * Correspondence: kjensen@ccny.cuny.edu; Tel.: +1-808-783-6299
}

Received: 3 August 2018; Accepted: 4 September 2018; Published: 7 September 2018

\begin{abstract}
Despite the growing number of remote-sensing products from satellite sensors, mapping of the combined spatial distribution and temporal variability of inundation in tropical wetlands remains challenging. An emerging innovative approach is offered by Global Navigation Satellite System reflectometry (GNSS-R), a concept that takes advantage of GNSS-transmitting satellites and independent radar receivers to provide bistatic radar observations of Earth's surface with large-scale coverage. The objective of this paper is to assess the capability of spaceborne GNSS reflections to characterize surface inundation dynamics in a complex wetlands environment in the Peruvian Amazon with respect to current state-of-the-art methods. This study examines contemporaneous ALOS2 PALSAR-2 L-band imaging radar, CYGNSS GNSS reflections, and ground measurements to assess associated advantages and challenges to mapping inundation dynamics, particularly in regions under dense tropical forest canopies. Three derivatives of CYGNSS Delay-Doppler maps (1) peak signal-to-noise ratio (SNR), (2) leading edge slope, and (3) trailing edge slope, demonstrated statistically significant logarithmic relationships with estimated flooded area percentages determined from SAR, with SNR exhibiting the strongest association. Aggregated Delay-Doppler maps SNR time series data examined for inundated regions undetected by imaging radar suggests GNSS-R exhibits a potentially greater sensitivity to inundation state beneath dense forest canopies relative to SAR. Results demonstrate the capability for mapping extent and dynamic wetlands ecosystems in complex tropical landscapes, alone or in combination with other remote-sensing techniques such as those based on imaging radar, contributing to enhanced mapping of these regions. However, several aspects of GNSS-R observations such as noise level, spatial resolution, and signal coherence need to be further examined.
\end{abstract}

Keywords: GNSS-R; CYGNSS; PALSAR-2; synthetic aperture radar; wetlands; inundation

\section{Introduction}

Freshwater ecosystems, such as streams, lakes, floodplains, marshes, and swamps, are estimated to cover between $14-29 \%$ of the Amazon basin area [1]. The seasonal flood pulse and runoff from heavy seasonal rains cause extensive and prolonged flooding of many vegetated regions of the Amazon. These dynamically inundated areas, in addition to forming biologically diverse habitats, also regulate 
biogeochemical processes such as the generation of atmospheric methane and the outgassing of carbon dioxide $[2,3]$. These flooding regimes can be impacted by future changes in rainfall, evapotranspiration and land use. The ability to accurately monitor the current state and changes in inundation extent would enable further examination of potential climatological and anthropogenic tipping points in these wetlands regions.

Satellite remote sensing is the only practical approach that can provide insight into the spatial and temporal dynamics of wetlands on a large scale on a continuous basis. Although they can offer high spatial resolution and sensitivity to photochemical properties of vegetation, optical sensors are severely limited in capturing inundation dynamics in tropical wetlands due to frequent cloud cover and difficulties detecting sub-canopy inundation $[4,5]$. Microwave sensors, on the other hand, are not significantly affected by clouds or changing solar illumination and are able to observe processes below vegetation canopy. However, tradeoffs exist in the use of microwave remote sensing with respect to characterizing dynamic tropical wetlands. Low spatial resolution (e.g., 20-40 km) radiometers and scatterometers have the advantage of frequent, often daily, coverage but limit detection to large wetlands or to regions where the cumulative area of small wetlands is a substantial portion of the instrument field of view. High spatial resolution $(<100 \mathrm{~m})$ synthetic aperture radar (SAR) provides more detailed spatial information but suffers from lower temporal coverage (6-12 days, but often more infrequent).

The nature of backscatter responses to surface water depends on the presence and character of vegetation cover. The complex assemblies of vegetation and dynamic surface hydrologic conditions often found in wetlands contribute to a diverse variety of backscatter signatures observed by SAR in these regions. Specular surfaces such as open water return low backscatter, while flooded vegetation can return a very strong backscatter response because of so-called double-bounce scattering. Depending on the density and structure of overlying vegetation, the radar energy can be substantially attenuated by the canopy. Apart from vegetation conditions, this attenuation depends largely on the sensor frequency (wavelength). With higher frequency, there is less radar energy penetration through the canopy and more contribution to backscatter from within-canopy volume scattering. L-band is the most common SAR frequency of choice used for remote sensing of wetland extent and dynamics over large regions because it provides superior canopy penetration and water surface discrimination relative to higher frequency microwave sensors [6,7].

Preliminary results based on data collections from the NASA's aircraft-mounted UAVSAR imaging radar over the Napo River in Ecuador and findings from Amazon-scale inundation dynamics mapped using PALSAR show notable limitations of L-band SAR-based inundation extent maps, particularly with systemic underestimation of inundated areas in dense forest [6,8,9]. Yuan et al. [10] found that increases in double-bounce backscatter with rising water levels in flooded vegetation was significantly lower in areas characterized by high amounts of woody biomass. Although SAR offers the current best sensitivity to inundation dynamics in wetlands, there remains a need for focused efforts to assess uncertainty in and improve the quality of inundation extent mappings provided by microwave remote sensing.

Global Navigation Satellite System reflectometry (GNSS-R) is a bistatic radar concept that takes advantage of L-band signals transmitted by navigation constellations such as the Global Positioning System (GPS). The GPS signals reflect from the Earth's surface with opportunity for global-scale bistatic radar coverage by appropriately positioned Earth-orbiting receivers. GNSS-R offers a new, complementary approach to monitoring inundation with Earth-orbiting radar. Although GNSS-R was first developed for measuring sea surface parameters [11,12], more recent studies have focused on the monitoring of terrestrial surface characteristics including soil moisture [13], vegetation phenology [14,15], mapping of flooded areas [16,17], and the detection of snow and ice [18,19]. Experimental campaigns from fixed [20,21], airborne [22-24], and Low-Earth Orbit platforms have confirmed the sensitivity of GNSS receivers to soil and biomass characteristics [25]. Parallel to these experimental developments, progress has been made with theoretical bistatic models that 
have improved the understanding of the forward-scattering effects taking place in GNSS-R [26-28]. This technology is gaining momentum as demonstrated by the launch of the UK TechDemoSat-1 (TDS-1) in July 2014 and the launch of the NASA Cyclone GNSS (CYGNSS) mission in December 2016, both of which carry GNSS-R receivers.

GNSS-R scattering and associated surface characteristics are determined from Delay-Doppler maps (DDM) of the bistatically-scattered signal. A DDM is produced by cross-correlating the recorded signal from a downward-looking antenna with a replica of the pseudorandom noise of the GNSS satellite over a range of time lags and carrier frequency offsets [29]. Various aspects of the DDM can be used for analysis (e.g., peak power, leading or trailing slope of the waveform, volume). Studies from a 2005 aircraft field campaign and the more recent TDS-1 satellite observations over known wetland areas have demonstrated the capability of GNSS-R DDM peak power measurements to detect standing water beneath low vegetation [30]. The forward scatter from GNSS reflected that signals strengthen in the presence of standing surface water in spite of vegetation attenuation. There have yet to be studies that quantify the amount of vegetation that GNSS-R can penetrate or examine the relative sensitivities of GNSS-R and L-band SAR backscatter when observing inundation below vegetation canopies.

The goal of this research is to assess the capability of spaceborne GNSS reflections to characterize surface inundation dynamics in a tropical wetlands complex with respect to current state-of-the-art SAR-based methods. In an integrative analysis of contemporaneous L-band SAR, GNSS-R, and ground measurements, this study examines the associated advantages and obstacles of mapping inundation dynamics under the canopy with these datasets.

\section{Materials and Methods}

\subsection{Study Area}

This study focuses on Peru's Ucayali-Marañon region of the Western Amazon (Figure 1). This region is home to the Pacaya Samiria National Reserve, a protected area bordered by the Marañon and Ucayali rivers. Spanning over $20,000 \mathrm{~km}^{2}$, this reserve encompasses the largest tropical flooded forest in the Peruvian Amazon and is the most expansive protected wetlands area in entire Amazon Basin. Topographic and climatic conditions, along with water availability, support the Pacaya Samiria's high ecological richness, biodiversity, and prevalent wetlands ecosystems. The seasonally dynamic flooding of this area with a diverse mosaic of vegetation and open water makes this an ideal study site for evaluating remote sensing assessments of inundation dynamics across a range of tropical vegetation conditions.

The dominant sources of water to these ecosystems are rainfall and upland run-off [1]. There is a pronounced rainy season which lasts approximately from December to April, with the seasonal flood pulse raising river water levels in the order of $10 \mathrm{~m}$ (Figure 2). As a result, a vast amount of the region experiences enhanced inundation for months every year. The duration of this flooding can vary considerably based on micro-topography and can drive the local vegetation composition. 
(a)

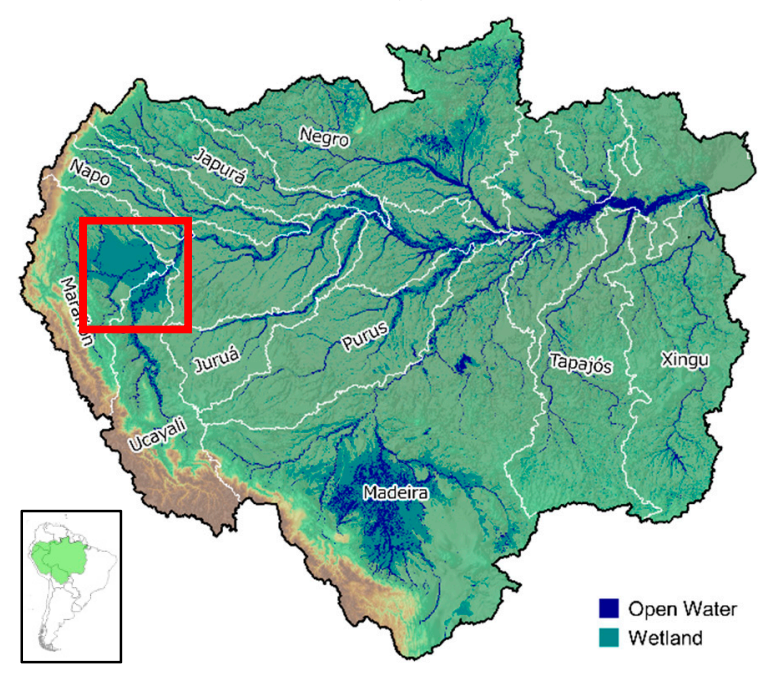

(b)

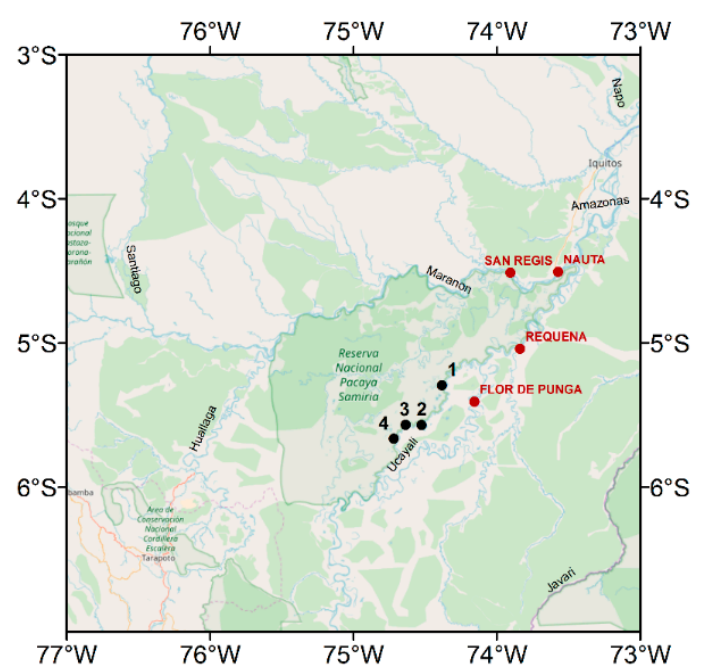

Figure 1. (a) The Amazon Basin, illustrating primary river sub-basins and freshwater ecosystem extent, with the study region boxed in red. Data sources: open water and wetland delineation from Reference [31]; sub-basin boundaries and GTOPO30 digital elevation model (DEM) from Reference [32]; (b) Extent of the study area, bounded by $3-7^{\circ} \mathrm{S}, 73-77^{\circ} \mathrm{W}$, containing the Pacaya Samiria National Reserve. Locations of biometry measurement sites 1-4 along Canal de Puinahua are labelled in black. Field station location where river gauge data are available are shown in red.

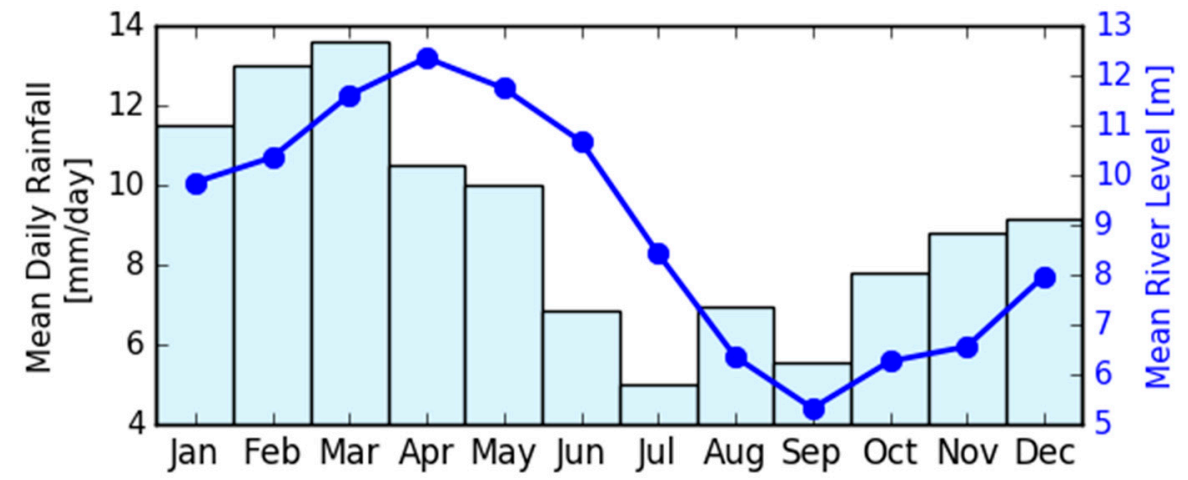

Figure 2. Mean monthly rainfall rate (mm/day) and mean monthly river level observed at Nauta field station $\left(4^{\circ} 30^{\prime} 26.5^{\prime \prime}, 73^{\circ} 34^{\prime} 23.88^{\prime \prime} \mathrm{W}\right)$, derived from daily observations over 2012-2017 provided by Servicio Nacional de Meteorologia e Hidrologia (Peru) [33].

\subsection{SAR Data and Classification}

\subsubsection{ALOS2 PALSAR-2 ScanSAR Multi-Tmporal Mosaics}

The Advanced Land Observing Satellite 2 (ALOS2) Phased Array L-band Synthetic Aperture Radar 2 (PALSAR-2) is an orbiting L-band SAR that was launched by the Japanese Aerospace Exploration Agency (JAXA) in May 2014. This study uses images acquired while the sensor was operating in ScanSAR mode, which is characterized by a wide swath up to $350 \mathrm{~km}$. This mode allows frequent data acquisition over large regions such as the Amazon [34]. Through the ALOS Kyoto and Carbon (K\&C) Initiative, processed dual polarized ( $\mathrm{HH}$ and $\mathrm{HV}$ ) mosaics have been assembled from ScanSAR data that have undergone radiometric calibration and terrain correction. These data have been formatted in 16-bit amplitude mosaics of topographic normalized backscatter coefficient $\left(\gamma^{0}\right)$ posted at $50 \mathrm{~m}$ resolution in $1^{\circ} \times 1^{\circ}$ tiles for each 14-day ScanSAR data acquisition cycle. Cycles between May 2014 through February 2018 were available for this analysis, 29 of which were found to either fully or partially observe the study area. Acquisition dates are summarized in Table A1 
(see Appendix A). Statistical analysis of backscatter was performed using amplitude values (digital numbers, $D N$ ). Final results were converted from $D N$ to normalized backscatter coefficients expressed in $\mathrm{dB}$ using the following equation:

$$
\gamma^{0}=10 \times \log _{10}\left(D N^{2}\right)+C F
$$

where CF is a calibration factor $(-83)$ used for standard PALSAR products [35].

\subsubsection{Image Classification}

SAR images were classified for open water and inundated vegetation to support evaluation of contemporaneous GNSS reflected signals. A two-step, object-oriented classification scheme was developed using temporal backscatter patterns (Figure 3), building on methods presented by Reference [36]. Thresholds applied in the decision tree classifier were derived from analysis of a number of small regions of interest (ROIs). Twelve ROIs were selected pertaining to different homogeneous land cover classes based on a priori knowledge of the reserve, making a distinction between forest and non-forest (NF) vegetation (Figure 4 and Table 1). Multi-temporal statistics of the $\mathrm{HH}$ - and HV-polarized backscatter time series were computed, including: minimum $\left(\gamma_{\mathrm{HH}-\mathrm{Min}}^{0}\right.$ $\left.\gamma_{\mathrm{HV}-\mathrm{Min}}^{0}\right)$, maximum $\left(\gamma_{\mathrm{HH}-\mathrm{Max}}^{0}, \gamma_{\mathrm{HV}-\mathrm{Max}}^{0}\right)$, mean $\left(\gamma_{\mathrm{HH}-\text { Mean }}^{0} \gamma_{\mathrm{HV}-\mathrm{Mean}}^{0}\right)$, and standard deviation $\left(\gamma_{\mathrm{HH}-\mathrm{Std}}^{0}, \gamma_{\mathrm{HV}-\mathrm{Std}}^{0}\right)$. Additional dry season information was collected including: (1) mean dry season HV-polarized backscatter $\left(\gamma_{\mathrm{HV}-\mathrm{DS}}^{0}\right)$ calculated from scenes observed in July-September (Cycles 27, 30, $53,56,79,82)$, and (2) median dry season normalized difference vegetation index (NDVI-DS) from Landsat 8 derived from cloud-free observations made in July-September of 2015-2017.

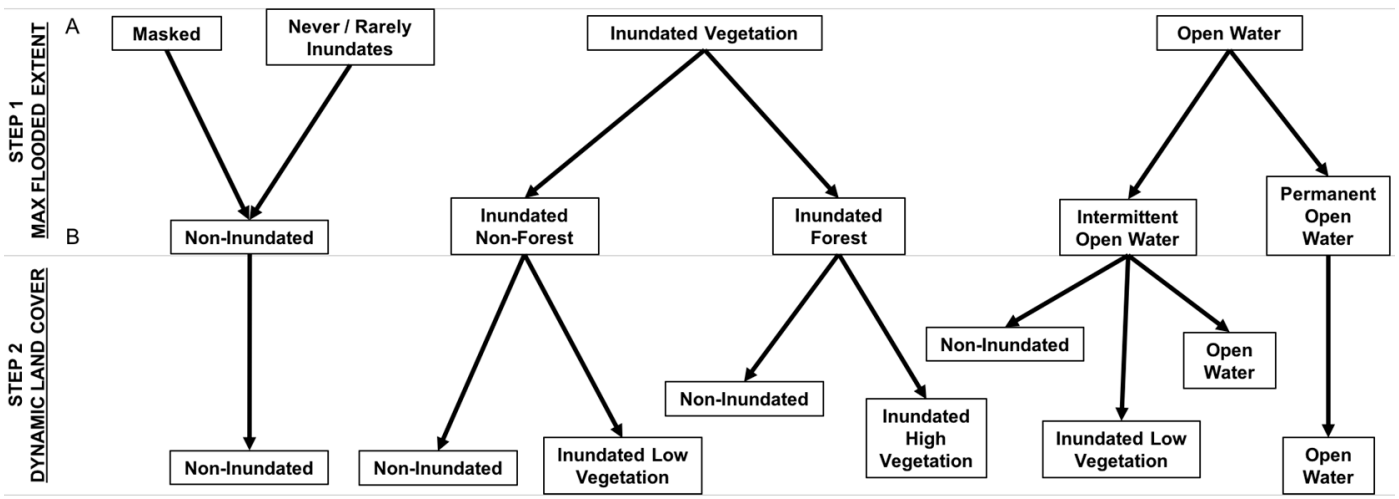

Figure 3. Two-step classification scheme used to classify static maximum flooded extent and dynamic land cover types and flooding status. The decision tree was implemented with thresholds derived from ROIs corresponding to associated homogenous land cover classes.

A general assumption was made that flooding occurs only in regions not significantly elevated above the river network, as supported by past literature e.g., [37,38]. A potential flood area mask was created based on the Height Above Nearest Drainage (HAND) index [39,40], which is effectively the elevation difference between a DEM pixel and the nearest pixel that is part of the drainage network. The HAND index was calculated from flow direction and a void-filled DEM from the HydroSHEDS database [41], that is derived from the Shuttle Radar Topography Mission (SRTM) [42] at 3 arc-second resolution. Similar to what was done by Reference [38], the stream network was defined by deriving flow accumulation for each pixel and identifying drainage pixels as those with 1000 or greater contributing pixels. The resulting stream network was further reduced by retaining segments with a Strahler stream order of three or greater. The height differences were calculated from the void-filled DEM provided by HydroSHEDS. A threshold of $20 \mathrm{~m}$ above the drainage network was used to mask out regions not prone to flooding. This approach supports a more appropriate estimate of the floodable area in regions of low topographic relief compared to estimates based on elevation 
alone, as regions of slowly increasing elevation may be accounted for as part of the inundatable wetlands complex.

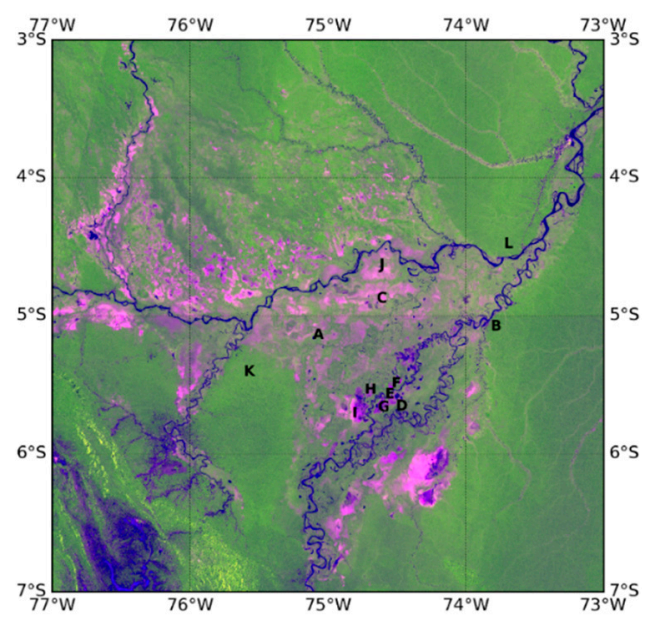

Figure 4. False-color composite of temporal mean ALOS2 PALSAR-2 ScanSAR backscatter (Red: HH, Green: HV, Blue: $\mathrm{HH} / \mathrm{HV}$ ) with locations of ROIs.

Table 1. Characteristics of selected ROIs and descriptive summaries of dry season NDVI and multi-temporal $\gamma^{0}$ statistics observed.

\begin{tabular}{|c|c|c|c|c|c|c|c|}
\hline ROI & Land Cover & Size(\#Pixels) & NDVI-DS & $\underset{(\mathrm{dB})}{\mathrm{fl}_{\mathrm{HH}-\mathrm{Mean}}^{0}}$ & $\begin{array}{c}\mathrm{fl}_{\mathrm{HV}-\text { Mean }}^{0} \\
(\mathrm{~dB})\end{array}$ & $\begin{array}{c}\mathrm{fl}_{\mathrm{HH}-\mathrm{Std}}^{0} \\
(\mathrm{~dB})\end{array}$ & $\begin{array}{c}\mathrm{fl}_{\mathrm{HV}-\mathrm{Std}}^{0} \\
\text { (dB) }\end{array}$ \\
\hline A & Seasonal Open Water & 307 & 0.37 & -11.4 & -18.3 & 4.8 & 4.9 \\
\hline $\mathrm{C}$ & Permanent Open Water & 443 & 0.01 & -18.3 & -24.8 & 1.6 & 0.9 \\
\hline $\mathrm{D}$ & Permanent Open Water & 1307 & -0.11 & -19.4 & -25.9 & 1.6 & 1.2 \\
\hline $\mathrm{E}$ & Seasonally Flooded NF & 516 & 0.65 & -5.5 & -14.2 & 2.1 & 1.3 \\
\hline $\mathrm{H}$ & Permanent Flooded NF & 279 & 0.57 & -6.7 & -15.7 & 1.6 & 1.1 \\
\hline I & Seasonally Flooded Forest & 1957 & 0.74 & -2.6 & -13.0 & 2.0 & 1.1 \\
\hline $\mathrm{J}$ & Seasonally Flooded Forest & 1576 & 0.72 & -4.1 & -12.9 & 2.2 & 1.1 \\
\hline $\mathrm{K}$ & Terra Firme Forest & 1807 & 0.76 & -7.3 & -11.9 & 1.2 & 1.1 \\
\hline $\mathrm{L}$ & Terra Firme Forest & 472 & 0.75 & -7.2 & -12.6 & 1.4 & 1.2 \\
\hline
\end{tabular}

In Step 1A (Figure 3), the maximum flooded extent observed in the entire ScanSAR time series (November 2014-February 2018) was delineated, distinguishing between open water, inundated vegetation and non-inundated areas. In Step 1B, masked regions and those found to never flood were merged into a single class named "Non-Inundated." The Inundated Vegetation class is split into Inundated Forest and Inundated Non-Forest classes, separated by vegetation density informed by $\gamma_{\mathrm{HV}-\mathrm{DS}}^{0}$. The Open Water class is divided into Permanent Open Water and Intermittent Open Water classes based on minimum temporal open water extent detected. The five static classes derived by the end of Step 1 each had its own decision rule-set developed for dynamic classification in Step 2. Here, classification was performed on individual scenes in the time series describing the flooding status at a given point in time.

Image segmentation was performed at both steps using the open-source RSGISLib Python module. Segmentation in Step 1 considered the following images: $\gamma_{\mathrm{HH}-\mathrm{Min}^{\prime}}^{0} \gamma_{\mathrm{HH}-\mathrm{Max}}^{0} \gamma_{\mathrm{HV}-\mathrm{Min}^{\prime}}^{0} \gamma_{\mathrm{HV}-\mathrm{Max}^{\prime}}^{0}$ $\gamma_{\mathrm{HV}-\mathrm{DS}}^{0}$, and NDVI-DS. In Step 2, the images used for segmentation include an individual cycle's $\mathrm{HH}-$ and HV-polarized backscatter, and the ratio of these two $(\mathrm{HH} / \mathrm{HV})$.

\subsubsection{Classification Evaluation}

Classification accuracy was evaluated for both Step 1 and 2 using independent approaches. The maximum flooded extent (Step 1) was evaluated against a static land cover map of the Pacaya 
Samiria National Reserve produced by the Instituto de Investigaciones de la Amazonia Peruana (IIAP) based on aerial surveys, ground observations, and Landsat imagery [43]. Pixels classified as intermittent open water in Step 1 were excluded from this assessment since only permanent water extent is mapped by IIAP. Furthermore, pixels classified as "Intervened Forest" and "Urban Population Centers" by IIAP were also excluded from the assessment as it was unclear if these were considered floodable by IIAP. This afforded 5,217,938 of testing pixels at 50m grid posting to assess against the maximum extent map ( $16 \%$ of the entire study area extent). The IIAP land cover classes were generalized to match the Step 1 classes, summarized in Table A3 (Appendix B).

Individual cycle classifications generated in Step 2 were more difficult to robustly assess due to lack of a time series of ground reference data. River level data from four monitoring stations in the reserve (locations shown in Figure 1b) were compared against the time series of flooded area percentage in a $5 \mathrm{~km}$ radius of each station.

\subsection{GNSS-R Data}

\subsubsection{CYGNSS}

The Cyclone GNSS (CYGNSS) mission was launched in December 2016. CYGNSS consists of a constellation of eight satellites in a low inclination orbit, each carrying a specialized GPS navigation receiver integrated with a reflections processor, with each receiver capable of receiving four GNSS reflection signals simultaneously [44]. With each satellite producing four DDMs per second, the CYGNSS constellation receives 32 concurrent measurements. Although the primary focus of the CYGNSS mission is to retrieve ocean surface winds, it also records measurements over land surfaces. Daily observations from 18 March 2017 through 28 February 2018 of CYGNSS Level 1 (L1) version 2.1 were provided by the CYGNSS Science Team, offering nearly a year of overlap with the PALSAR-2 ScanSAR time series (Cycles 71, 74, 77, 79, 82, 85, 88, 91, 93).

\subsubsection{Data Processing}

This analysis focuses on three aspects of the DDM: The peak signal to noise ratio (SNR), leading edge slope (LES) and trailing edge slope (TES). SNR, as defined in Equation (2), is provided as an observable corrected for antenna gain and range in the L1 dataset, while the LES and TES were derived from the two-dimensional (Doppler $\times$ delay) bistatic radar cross section DDM (Figure 5). There are 27 quality flags associated with each DDM observation, some of which are critical for ocean applications but not necessary for terrestrial studies. A summary of the quality flags that were used in this analysis is presented in Table A2 (Appendix A). As observed with traditional imaging radar, the incidence angle $\left(\theta_{\text {inc }}\right)$ affects the signal path length and can noticeably impact the signal particularly at both very steep and very shallow angles. For these reasons, observations with incidence angles of $<15^{\circ}$ and $>60^{\circ}$ were excluded from the analysis.

$$
S N R=10 \times \log _{10}\left(\frac{P-N}{N}\right)
$$

where $P$ is maximum power of the DDM, and $N$ is the background noise level.

The baseline Level 2 CYGNSS wind speed product has a nominal spatial resolution of $25 \mathrm{~km} \times 25 \mathrm{~km}$ (centered on the specular reflection point), but the native resolution is much greater. CYGNSS averages multiple DDM bins together to yield the $25 \mathrm{~km} \times 25 \mathrm{~km}$ footprint. However, the L1 data products can be exploited to optimize resolution over wetlands. Previous analyses have shown that over land surface, particularly wetlands, there is a dominant coherent component to the reflected signal. Thus, the active scattering area is defined by the first Fresnel zone, $\sim 650 \mathrm{~m}$ at smaller incidence angles $\left(<40^{\circ}\right)$ and reaches up to $\sim 1 \mathrm{~km}$ at larger angles $\left(>50^{\circ}\right)$ [30]. The effective cross-track resolution is assumed as this first Fresnel zone size, but the along-track resolution is elongated since CYGNSS 
measurements are averaged incoherently over $1 \mathrm{~s}$ and the distance traveled by the specular point during this time is $\sim 6 \mathrm{~km}$.
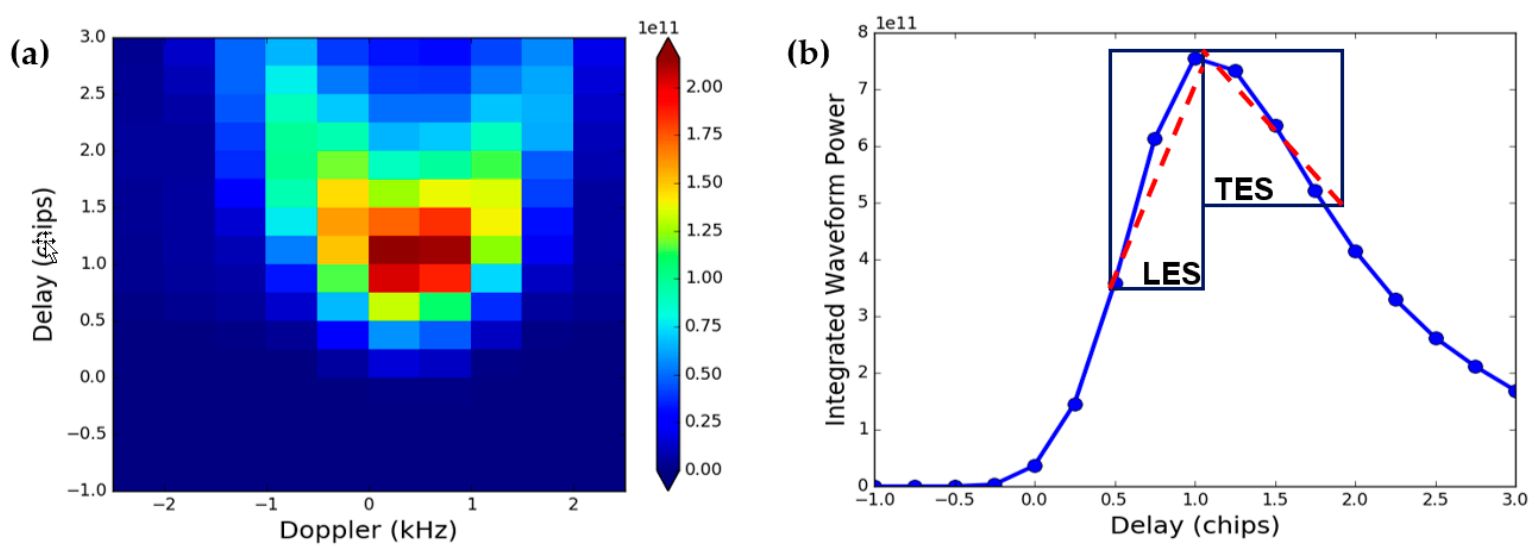

Figure 5. (a) Example of a bistatic radar cross section Delay Doppler map (DDM); (b) integrated delay waveform (IDW) derived from (a). The leading edge slope (LES) is estimated from the peak in the IDW and the two preceding points, while trailing edge slope (TES) is derived from the IDW peak and three following points.

CYGNSS DDM SNR, LES, and TES values were mapped to a fixed $50 \mathrm{~m}$ grid identical to the one at which the ALOS2 PALSAR-2 ScanSAR mosaics are posted, adopting a method first presented by Reference [45]. The size of the semi-major and semi-minor axes of the ellipses corresponding to individual DDM footprints were defined using Equations (3) and (4), respectively:

$$
\begin{gathered}
\Delta x=2 \times \frac{1}{\sin \varepsilon}\left(\frac{R_{r x} R_{t x} \lambda}{R_{r x}+R_{t x}}\right)^{1 / 2}+6 \mathrm{~km} \\
\Delta y=2 \times\left(\frac{R_{r x} R_{t x} \lambda}{R_{r x}+R_{t x}}\right)^{1 / 2}
\end{gathered}
$$

where $\varepsilon$ is the elevation angle of the reflected signal with respect to the local tangent plane at the specular point, or $90^{\circ}-\theta_{\text {inc }} ; R_{r x}$ is the distance between the receiver antenna and the specular point; $R_{t x}$ is the distance between the transmitter antenna to the specular point; $\lambda$ is the wavelength of the signal $(0.19 \mathrm{~m})$. Derivation of these equations is described in more detail by Reference [46].

The footprint ellipse is rotated by the angle of the track direction around the specular point, and all grid cells found to be in the ellipse are assigned the corresponding DDM values. DDM footprints were examined using the data posted at this $50 \mathrm{~m}$ grid (Section 3.4.1). However, a pixel-wise time series analysis cannot be done properly using these data since in this case individual DDM SNR, LES, and TES values are not representative of any single $50 \mathrm{~m}$ pixel, but rather the entire footprint. Footprints were aggregated to a $0.01^{\circ}(\sim 1 \mathrm{~km})$ grid, where grid cells are assigned DDM values when there is $50 \%$ or greater coverage by a DDM footprint. Multi-temporal observations were assessed in Sections 3.4.2 and 3.4.3 using DDM values at this grid posting.

\subsection{Ground Reference Data}

Field data were collected in July-August 2017 during low-water conditions in the Pacaya Samiria National Reserve to assess the impact of biomass on the ability to detect inundation with SAR and GNSS-R observations. During the 18-day excursion, ground measurements were collected on vegetation structure and past inundation depth history at four primary floodplain sites along Canal de Puinahua (locations shown in Figure 1b; photographs shown in Figure 6). 
(a)

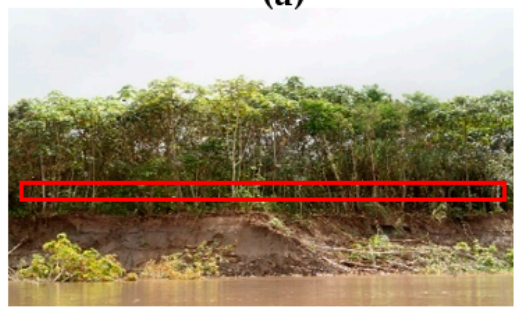

(d) (b)

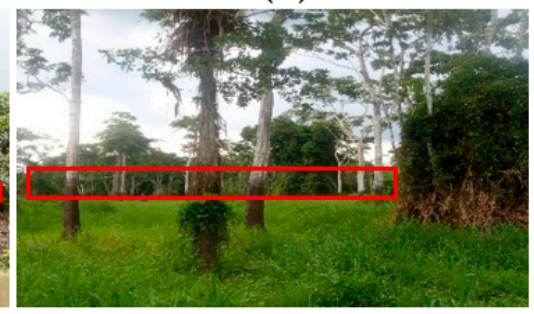

(e) (c)

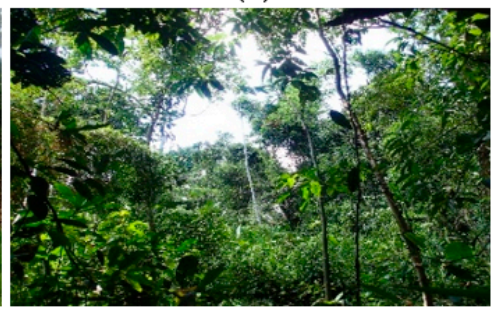

(f)
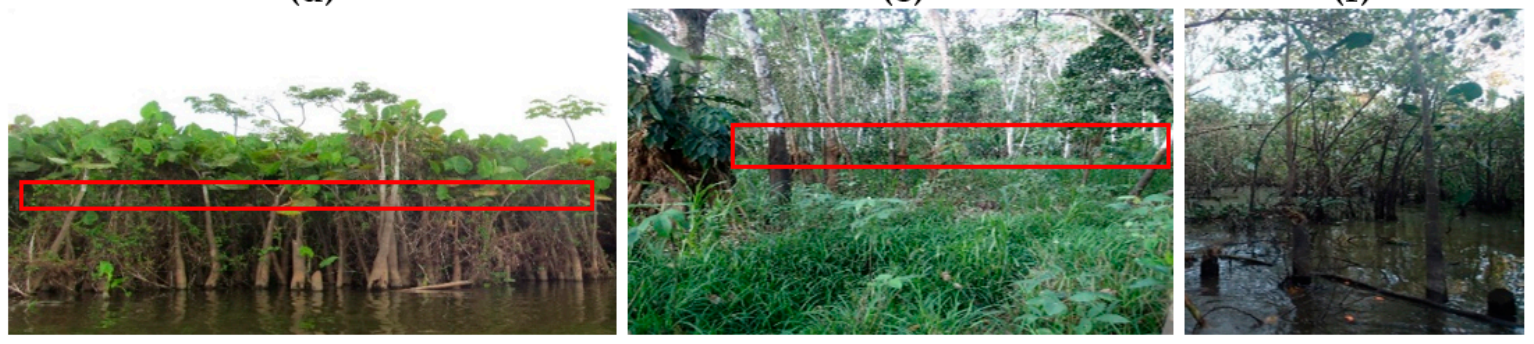

Figure 6. Variety of floodplains observed at study sites (shown in Figure 1b) in Pacaya Samiria at low water season. (a) View of river bank near Site \#1, (b) open area in Site \#1(in Figure 1b) with sparse tree cover dominated by Pseudobombax munguba; (c) Dense canopy cover found in Site \#2 (in Figure 1b); (d) inundated aquatic shrub species (Montrichardia arborescens) found along margins of lake at Site \#3(in Figure 1b); (e) denser tree cover and understory found in Site \#3 (in Figure 1b); (f) inundated swamp found at Site \#4 (in Figure 1b). Examples of high flood marks on trees (shown red rectangles) indicate the level of previous inundation.

\subsubsection{Circular Plots and Biomass Estimation}

Biometric measurements were made at seven circular plots ( $15 \mathrm{~m}$ radius each) hosting varying levels of biomass density. Stand leaf area index (LAI) $\left(\mathrm{m}^{2} \mathrm{~m}^{-2}\right)$ was estimated using the LAI-2200C plant canopy analyzer (Li-Cor, Inc., Lincoln, Nebraska, NE, USA) following the procedure detailed in Appendix C. Canopy closure (\%) was estimated using a densiometer. Four readings were taken in each of the cardinal directions in each quadrant and then averaged. In addition, evidence of past flooding stage was recorded to the nearest $10 \mathrm{~cm}$. Individual tree measurements were recorded for each living tree $\geq 5 \mathrm{~cm}$ in diameter found in each plot. Diameter at breast height (D) was measured with a diameter tape at $1.3 \mathrm{~m}$ and recorded to the nearest $0.1 \mathrm{~cm}$. Height to the base of the live crown (HC) and total height (HT) were estimated using a distance meter; and crown depth (CD) was calculated as the difference between HT and HC. All trees were identified as their species or genus when possible and assigned a wood density value ( $\rho$, oven-dry mass over green volume, $\mathrm{g} \mathrm{cm}^{-3}$ ) from the Global Wood Density Database [47,48]. Unidentified trees were assigned the average $\rho$ for their containing plot. Aboveground biomass (AGB) was estimated for individual trees using the Equation (5), an allometric equation for moist pantropical forests developed by Reference [49]. AGB density $\left(\mathrm{Mg} \mathrm{ha}^{-1}\right)$ was estimated for each plot by summing the individual tree AGBs per plot.

$$
A G B_{\text {est }}=0.0673 \times\left(\rho D^{2} H T\right)^{0.976}
$$

\subsubsection{Line Transects}

In addition to the detailed measurements recorded at circular plots, a limited set of biometry measurements were collected along six line transects ( 0.5-1 km in length) in $25-50 \mathrm{~m}$ intervals, depending on canopy conditions. Measurements taken at each point included: LAI, canopy closure, and any past inundation depth-all collected in a similar fashion as those recorded in the circular plots (detailed in Section 2.4.1). One longer transect ( $\sim 3 \mathrm{~km}$ in length) was made via canoe through an inundated swamp. Although no biometry measurements were collected along this transect, notes on 
vegetation character, inundation, and geolocated photographs were recorded approximately every $250 \mathrm{~m}$.

\subsection{Sensitivity Analysis}

The SAR-based classifications were utilized in two general ways: (1) To assist in interpreting CYGNSS DDM observations, and (2) to evaluate against CYGNSS DDMs with respect to sensitivity to surface inundation. First, the footprints of CYGNSS DDMs were examined with contemporaneous flooded state, estimated using the derived PALSAR-2 classifications. Secondly, the limitations of the SAR-based classification were assessed with ground information. Time series of both the SAR-based classifications and CYGNSS DDMs of known areas were examined.

The Global Forest Watch developed a pantropical $30 \mathrm{~m}$ resolution dataset of estimated woody AGB density of the year 2000 [50]. This dataset was derived from a combination of ground measurements, Geoscience Laser Altimeter System (GLAS) LiDAR, Landsat 7 ETM+ surface reflectance, elevation, and biophysical variables. Although this is a dated estimate, a large portion of the study area is protected and hence, large amounts of drastic changes in vegetation over the past 18 years are assumed unlikely. Plot level AGB density values were compared against corresponding values in GFW-AGB to assess the suitability of large scale analysis using the GFW-AGB dataset as a proxy for biomass density across the study area. The GFW-AGB data were co-registered to the $50 \mathrm{~m}$ grid at which the PALSAR-2 SAR data were posted using nearest-neighbor interpolation and used to assess the impact of biomass on inundation detection.

\section{Results}

\subsection{Multi-Temporal SAR Signatures}

Multi-temporal HH- and HV-polarized radar backscatter from PALSAR-2 and dry-season NDVI from Landsat 8 were examined in 12 ROIs (representing six land cover types). Figure 7 shows the histograms of these classes (ROIs of the same class were merged) for eight multi-temporal images. A thresholding approach was developed to delineate flooded extent by land cover type, as demonstrated in previous studies of classifying wetland types with L-band SAR e.g., [6,31,36,51]. Open water, which presents a highly reflective surface for which specular radar scatter dominates, exhibits low backscatter values. Thus, the maximum extent of open water regions can be delineated with $\gamma_{\mathrm{HH}-\mathrm{Min}}^{0}$ and $\gamma_{\mathrm{HV}-\mathrm{Min}}^{0}$ (Figure 7a,c). Regions of temporally intermittent open water can be differentiated from permanent open water areas with $\gamma_{\mathrm{HV}-\mathrm{Max}}^{0}$ (Figure $7 \mathrm{~d}$ ). High biomass vegetation where any inundation occurs can be identified by high $\gamma_{\mathrm{HH}-\mathrm{Max}}^{0}$ (Figure 7c) due to plant-water double bounce scattering. Low vegetation (e.g., pioneer formations, such as grasses and other herbaceous species) where inundation may occur poses a more complex backscatter dynamic with greater temporal variation (Figure 7e,f) due to factors like soil moisture, vegetation structure, and varying inundation depth. If partially flooded, double bounce interactions may yield high HH-polarized backscatter, but if submerged, these regions will appear dark with low backscatter. Forested areas observe both greater $\gamma_{\mathrm{HV}-\mathrm{DS}}^{0}$ (Figure 7g) and NDVI-DS (Figure 7h) than lower density, non-forest vegetation.

\subsection{SAR Classification}

The classification algorithm and decision tree derived for Step 1 are illustrated in Figure 8a, with the resulting map shown in Figure $8 \mathrm{~b}$. This maximum flooded extent classification showed generally high agreement with the IIAP Pacaya Samiria land cover map, depicting inundated regions with an overall accuracy of $91.8 \%$ and kappa index value of 0.84 (Table 2). 
(a)

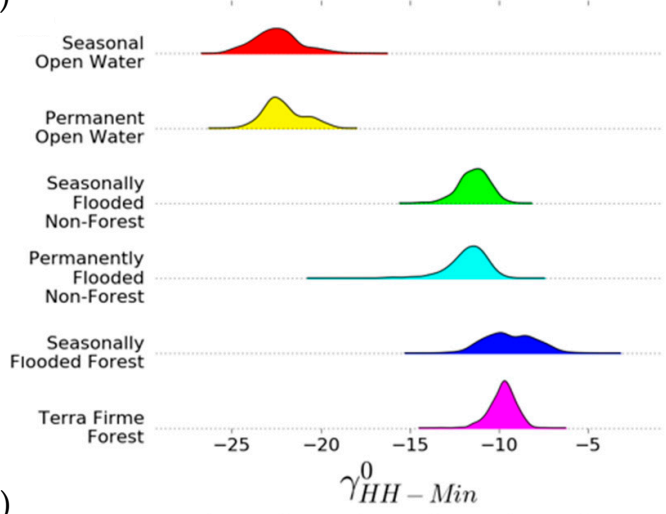

(c)

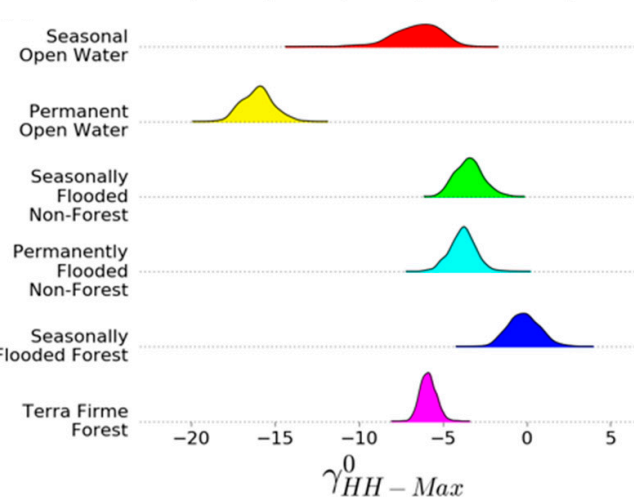

(e)

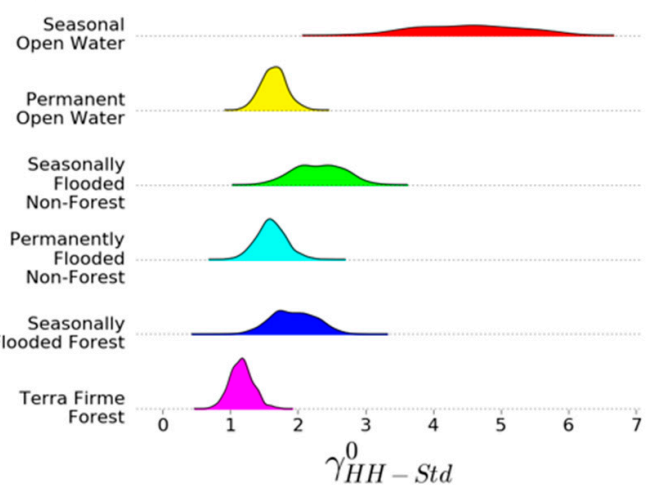

(g)

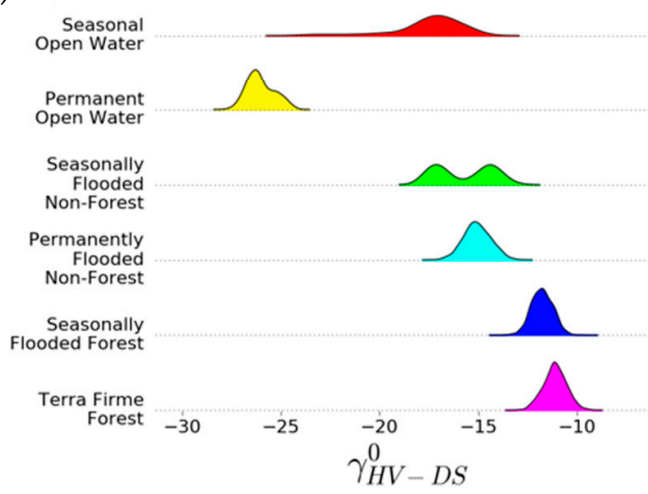

(b)

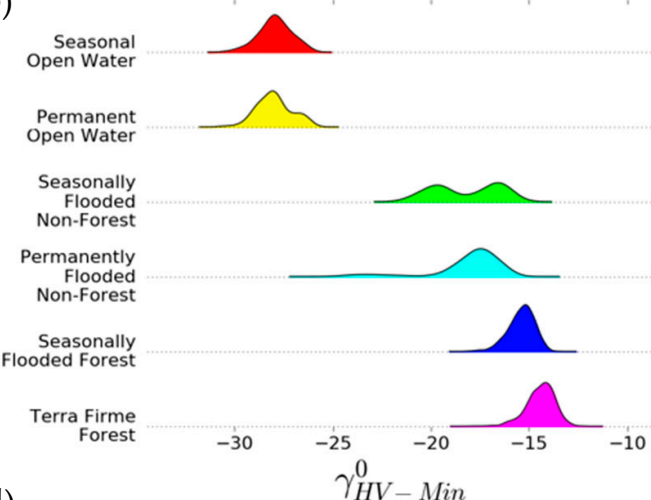

(d)

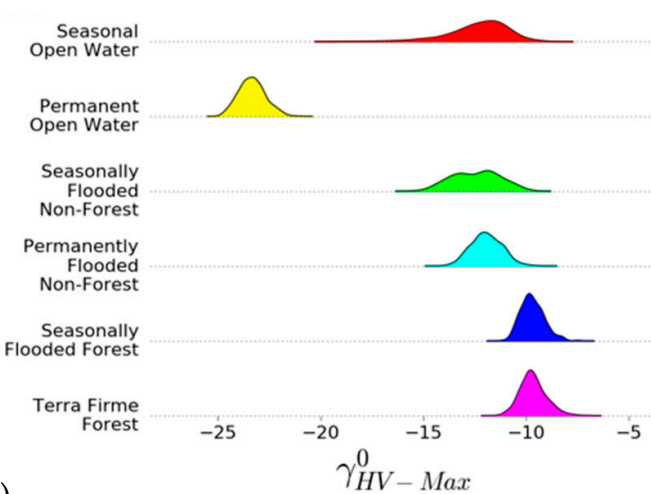

(f)

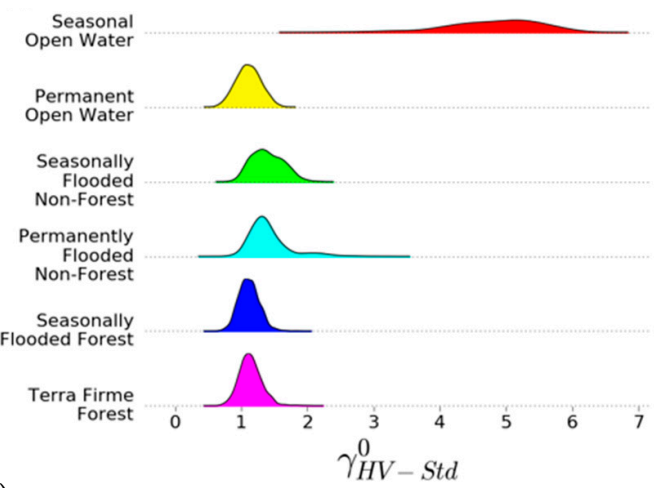

(h)

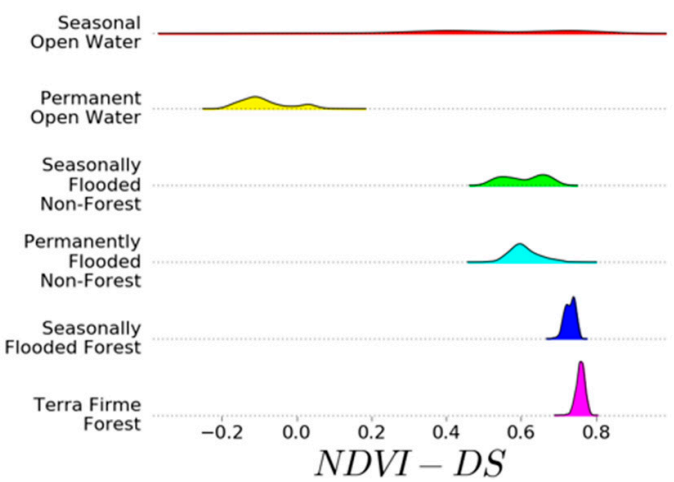

Figure 7. Distribution of multi-temporal $\gamma^{0}$ and NDVI statistics by land cover type from selected ROIs representing a variety of landcover classes: (a) $\gamma_{\mathrm{HH}-\mathrm{Min}^{\prime}}^{0}$ (b) $\gamma_{\mathrm{HV}-\mathrm{Min}^{\prime}}^{0}$ (c) $\gamma_{\mathrm{HH}-\mathrm{Max}^{\prime}}^{0}$ (d) $\gamma_{\mathrm{HV}-\mathrm{Max}^{\prime}}^{0}$ (e) $\gamma_{\mathrm{HH}-\mathrm{Std}^{\prime}}^{0}$ (f) $\gamma_{\mathrm{HV}-\mathrm{Std}}^{0}$ (g) $\gamma_{\mathrm{HV}-\mathrm{DS}}^{0}{ }^{\prime}$ (h) NDVI-DS. Thresholding schemes for implementation of the decision tree classification are developed from these histograms. 
(a)

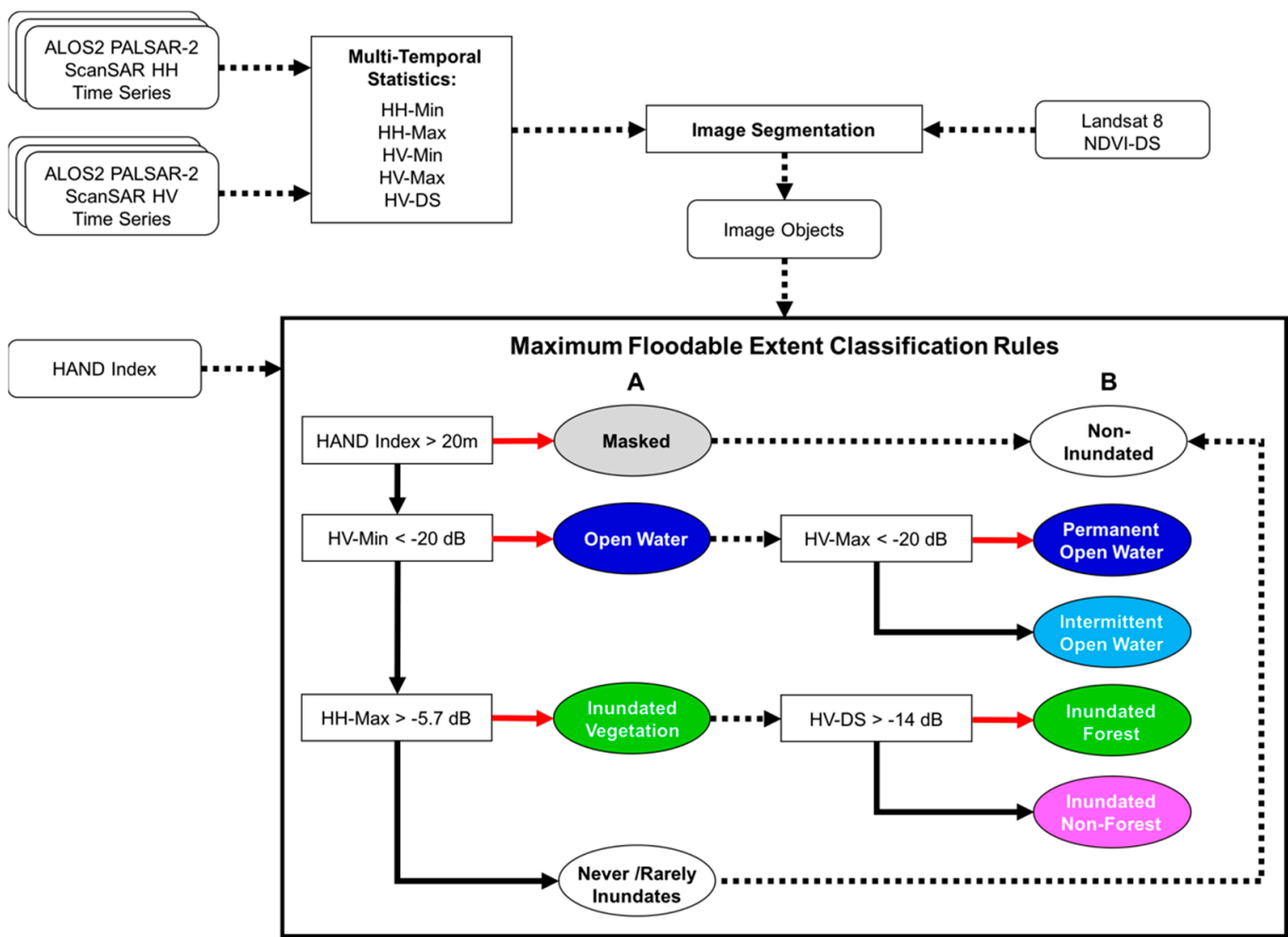

(b)

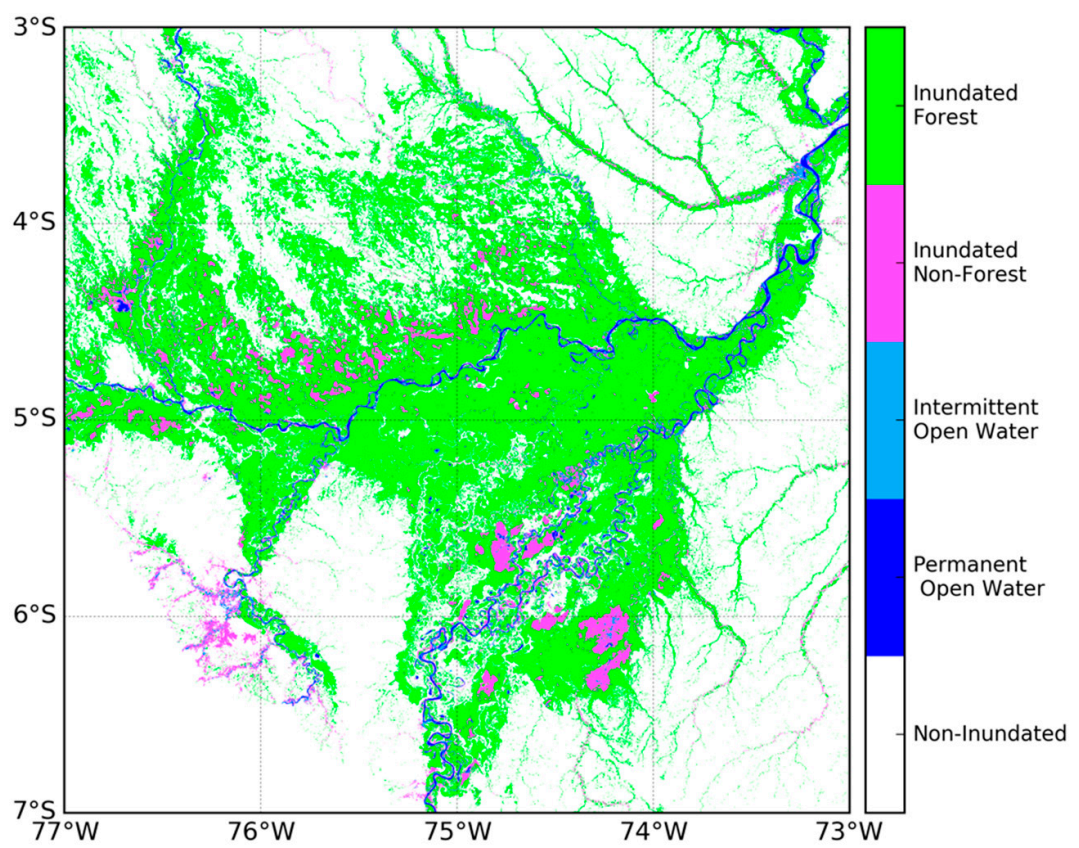

Figure 8. (a) Step 1, object-based classification algorithm for maximum flooded extent. Boxes with rounded edges indicate inputs; boxes with sharp corners indicate a process/decision; ovals indicate assigned classes. In the decision tree, bold red arrows correspond with "True" and bold black arrows with "False". (b) Maximum flooded extent classification map.

The highest commission error was observed for the Non-Flooded class $(20.2 \%)$, which suggests notable underestimation of flooded maximum extent. Open Water, Inundated Non-Forest, and Inundated Forest each had comparable omission error rates (8-11\%). Floodable regions of low vegetation areas may potentially have been classified as Open Water at maximum extent if they were completely submerged, but may have been identified as Inundated Non-Forest by the IIAP map. 
Some regions classified as Non-Inundated noticeably follow along river banks. Many of these regions exhibit variations in micro-topography with elevated embankments that have shallow or no inundation depths as detected by the SAR observations. Furthermore, it is possible that regions of particularly dense canopy conditions limit the ability for radar to detect inundation. Other potential error sources that are not related to the backscatter retrieval include: (1) Disagreement in definitions of Forest and Non-Forest vegetation, (2) co-registration issues between IIAP map and PALSAR-2 ScanSAR mosaics and (3) changes in river extent and vegetation regimes since the IIAP map was derived in 2002.

Table 2. Accuracy assessment of Step 1 maximum flooded extent classification compared with IIAP reference map of Pacaya Samiria National Reserve.

\begin{tabular}{|c|c|c|c|c|c|c|c|c|}
\hline \multicolumn{9}{|c|}{ IIAP Reference } \\
\hline \multirow{8}{*}{ 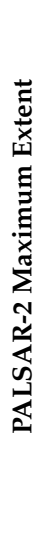 } & & $\begin{array}{l}\text { Open } \\
\text { Water }\end{array}$ & $\begin{array}{l}\text { Inundated } \\
\text { Non-Forest }\end{array}$ & $\begin{array}{l}\text { Inundated } \\
\text { Forest }\end{array}$ & $\begin{array}{c}\text { Non- } \\
\text { Inundated }\end{array}$ & Total & $\begin{array}{c}\text { User's } \\
\text { Accuracy }\end{array}$ & $\begin{array}{c}\text { Commission } \\
\text { Error }\end{array}$ \\
\hline & Open Water & 38,860 & 3617 & 23 & 3 & 42,503 & $91.4 \%$ & $8.6 \%$ \\
\hline & $\begin{array}{l}\text { Inundated } \\
\text { Non-Forest }\end{array}$ & 2798 & 275,685 & 13,571 & 167 & 292,221 & $94.3 \%$ & $5.7 \%$ \\
\hline & $\begin{array}{l}\text { Inundated } \\
\text { Forest }\end{array}$ & 657 & 17,485 & $3,006,949$ & 19,282 & $3,044,373$ & $98.8 \%$ & $1.2 \%$ \\
\hline & Non-Inundated & 33 & 6579 & 363,945 & $1,468,284$ & $1,838,841$ & $79.8 \%$ & $20.2 \%$ \\
\hline & Total & 42,348 & 303,366 & $3,434,488$ & $1,487,736$ & $5,217,938$ & & \\
\hline & $\begin{array}{l}\text { Producer's } \\
\text { Accuracy }\end{array}$ & $91.8 \%$ & $90.9 \%$ & $88.8 \%$ & $98.7 \%$ & & & \\
\hline & $\begin{array}{c}\text { Omission } \\
\text { Error }\end{array}$ & $8.2 \%$ & $9.1 \%$ & $11.2 \%$ & $1.3 \%$ & & & \\
\hline
\end{tabular}

The classification of individual ScanSAR cycles in Step 2 was performed using the scheme summarized in Figure 9. Daily river level at four field stations (locations shown in Figure 1b) were compared with the corresponding percentage of local classified flood extent (considering a radius of $5 \mathrm{~km}$ around each station) (Figure 10). Since the relationship between river level and flood extent is not linear, observations were fit to a logistic curve and demonstrated reasonable goodness of fit $\left(\mathrm{R}^{2}\right.$ ranging from $\left.0.92-0.95\right)$.

\subsection{Biometry Measurements and Biomass Estimation}

A variety of primary and secondary forest stands were surveyed, providing a range of biomass conditions for inundation detection assessment. In Appendix D, biometry data of circular plot characteristics are summarized in Table A4 and descriptive statistics derived from line transects are summarized in Table A5. Each stand at which circular plots were made showed evidence of past flooding, while 78 out of the 81 transect points surveyed did so. Circular plot-level estimated AGB density ranged from $42.2-278.3 \mathrm{Mg} \mathrm{ha}^{-1}$. Although this only provides seven data points, these values were compared to the GFW-AGB dataset and illustrated in Figure 11. The GFW dataset appears to over-estimate AGB density compared to our biometry collections. The one site where the GFW-AGB density was found to be less than the plot-measured AGB had considerable biomass contributed to from several ficus trees (Ficus trigonata) which exhibited large networks of exposed roots. It is possible that these unique features could lead to an underestimation of standing biomass in the GFW data. The strong, positive correlation (Pearson's correlation coefficient $=0.835$, two-tailed $p$-value $=0.019$ ) is encouraging, and the GFW-AGB dataset was deemed suitable for large-scale analysis. 


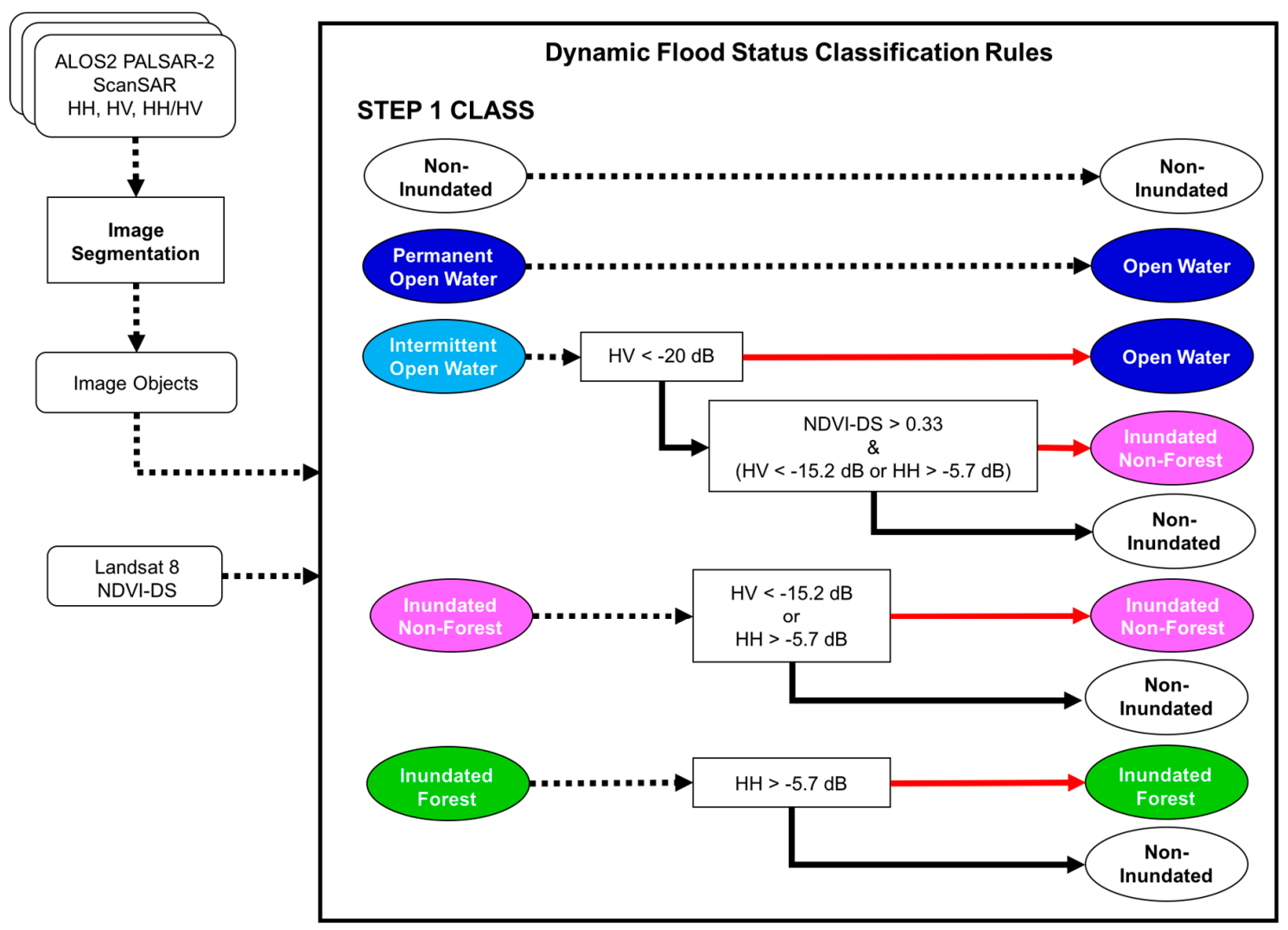

Figure 9. Step 2 object-based classification algorithm for delineating time series inundation state. Boxes with rounded edges indicate inputs; boxes with sharp corners indicate a process/decision; ovals indicate assigned classes. In the decision tree, bold red arrows correspond with "True" and bold black arrows with "False".

Transect measurements demonstrated positive relationships among vegetation structure metrics, with observed LAI and canopy closure shown in Figure 12a, and each of these compared to GFW-AGB in Figure 12b,c respectively. Figure 13a shows the long transect made through a swamp with a vegetation gradient. It leads from a small lake (point 0 ) through tall grasses and other herbaceous species (points 1,7,8), mixed herbaceous and sparse trees (points 2-6), mixed trees and herbaceous communities (points 9-13), and forest (points 14-18), ending near the river bank. At the time of observation (30 July 2017) in the middle of low-water season, points 1-15 were inundated while 16-18 were dry but showed evidence of past seasonal flooding to depths $>0.5 \mathrm{~m}$. This transect sampled three $0.01^{\circ} \times 0.01^{\circ}$ grid cells (labelled A, B and C in Figure 13a) that displayed a general increase in biomass density. A and B are both primarily inundated swamp, with B hosting greater amounts of trees, and C primarily observed as a seasonally inundated forest. The GWF-AGB density and $\gamma_{\mathrm{HV}-\mathrm{DS}}^{0}$ (Figure 13b) both generally increase across the transect and appear strongly correlated, with the last three points (16-18) exhibiting an indication of high biomass. 
(a)

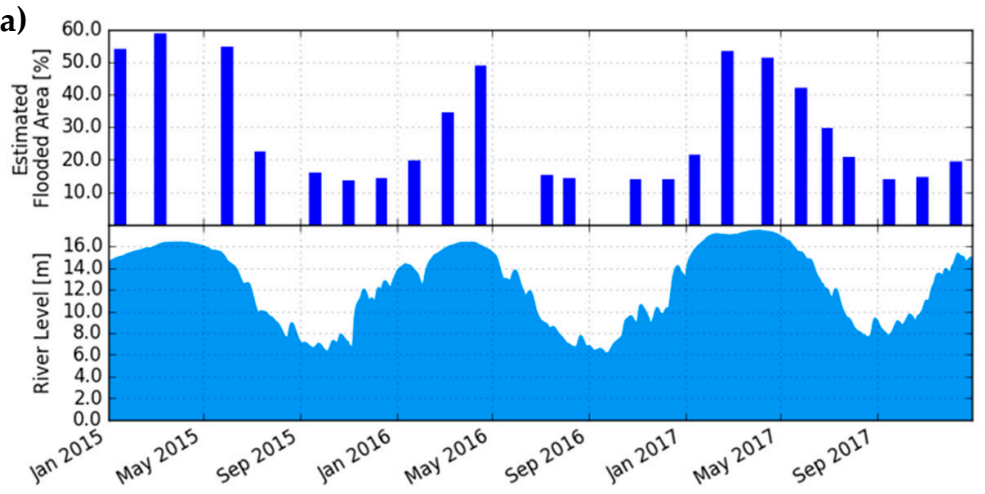

(b)

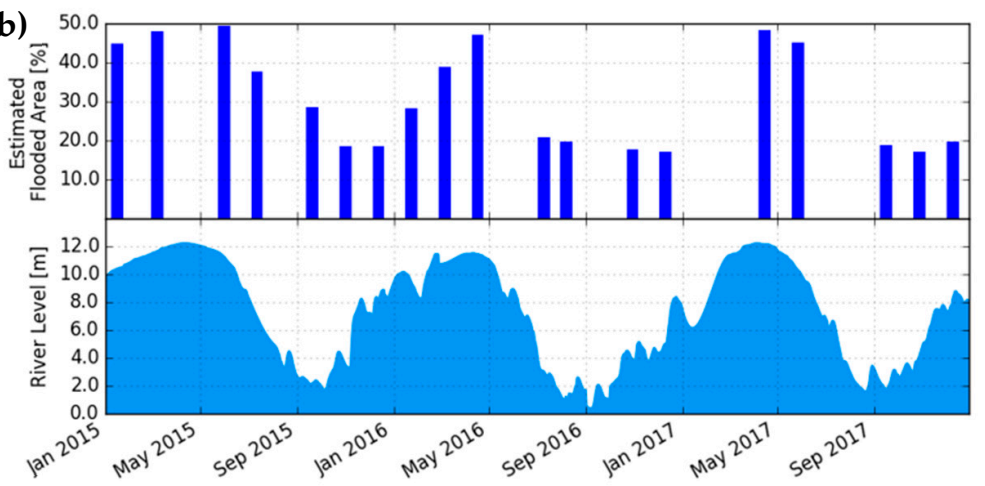

(c)

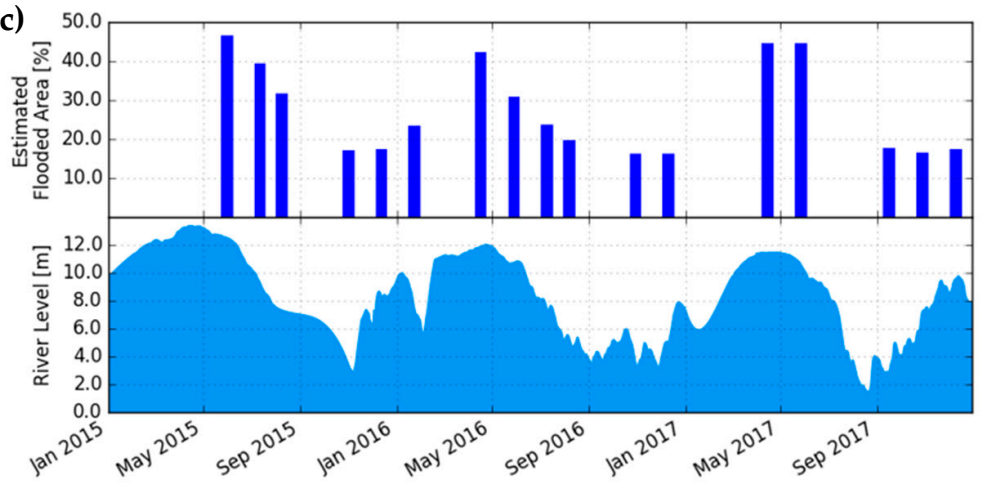

(d)

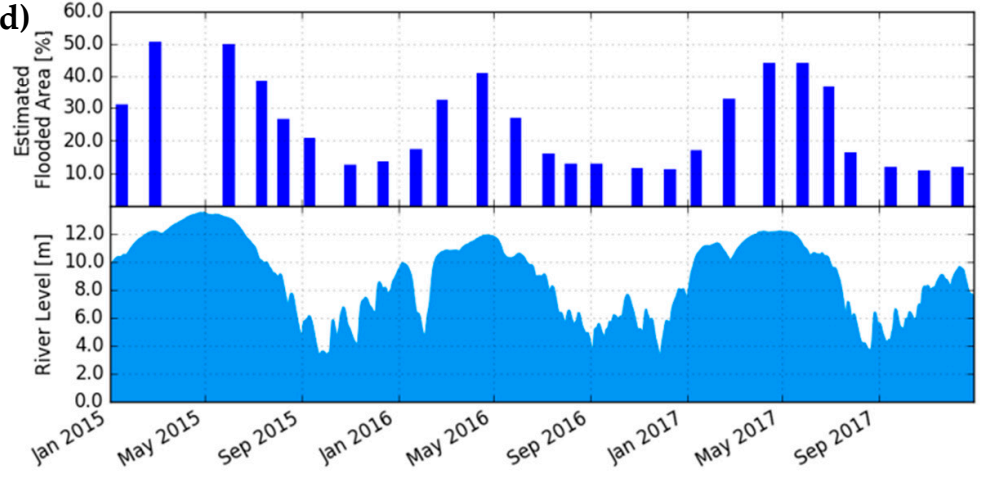

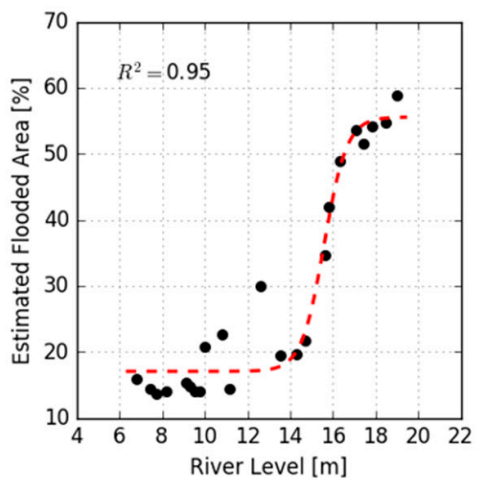
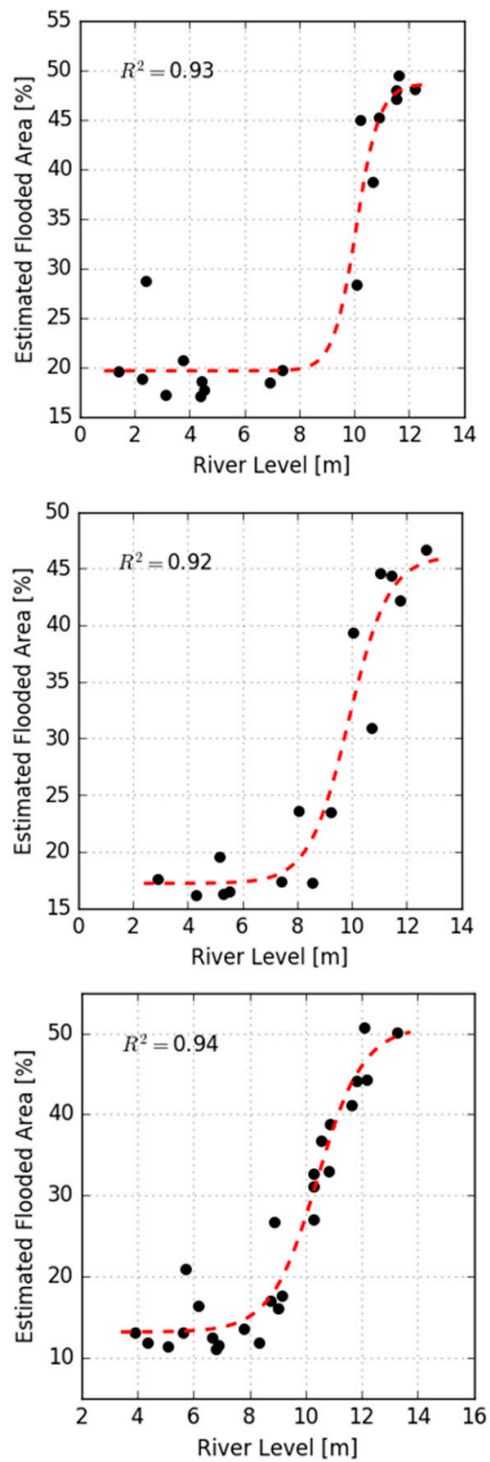

Figure 10. Time series of PALSAR-2 classified flooded area percentage (open water, inundated non-forest and inundated forest) in the surrounding area within a $5 \mathrm{~km}$ radius and river level measurements (left) and scatter plots of corresponding values fitted to a logistic model (right) of the four field stations with locations shown in Figure 1: (a) Flor de Punga, (b) Requena, (c) Nauta, (d) San Regis. 


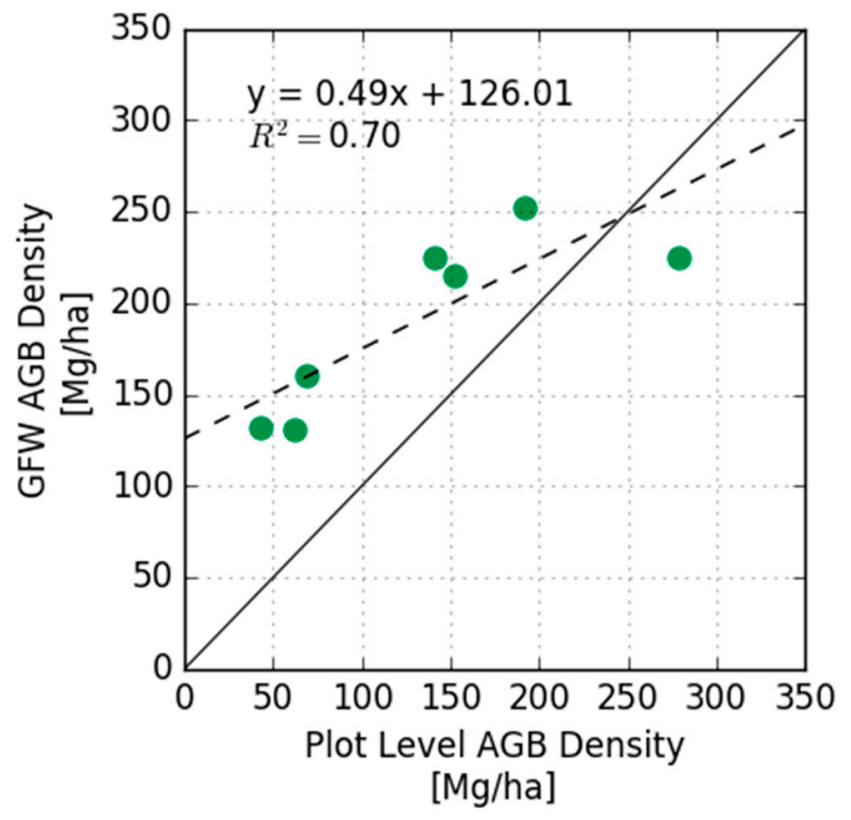

Figure 11. Plot-level AGB density ( $x$-axis) versus GFW-AGB density ( $y$-axis). 1:1 line shown in solid black. Linear fit shown in dashed black, with equation and $r$-squared reported.

(a)

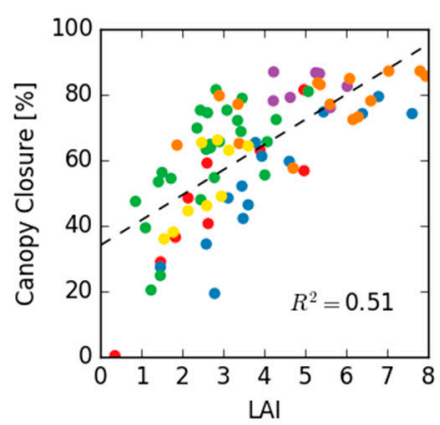

(b)

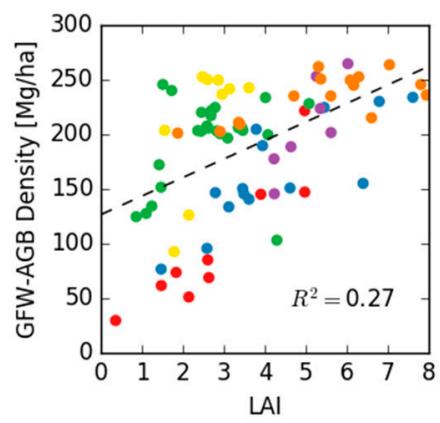

(c)

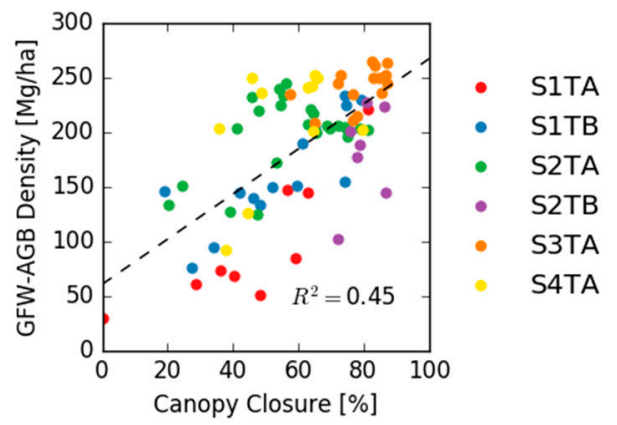

Figure 12. (a) Relationship between LAI and canopy closure measured at transect points; (b) transect LAI ( $x$-axis) versus GFW-AGB density ( $y$-axis); (c) transect canopy closure ( $x$-axis) versus GFW-AGB density ( $y$-axis). Color of points corresponds to transect. Linear best-fit lines shown in dashed black, with r-squared values reported.

\subsection{Evaluation of SAR and GNSS-R Inundation Detetction}

\subsubsection{Footprint Analysis of SAR Classification vs. CYGNSS DDMs}

For each CYGNSS footprint observed during each of the 14-day ALOS2 PALSAR-2 ScanSAR cycles, the percentage of flooded area in each footprint was calculated based on the PALSAR-2 dynamics inundation classification and plotted against corresponding CYGNSS DDM observations. Summary plots are shown in Figure 14, with the top row (Figure 14a-d) presenting SNR, center row (Figure 14e-h) presenting LES, and bottom row (Figure 14i-l) presenting TES. The leftmost column displays the relationship observed between the percentage of all flooded area (Open Water, Inundated Non-Forest, and Inundated Forest) of all CYGNSS footprints and the respective DDM values. The center left column illustrates a subset of these footprints, showing only those with negligible amount of classified flooded vegetation $(<5 \%)$ and focusing on the dependence of DDM measurements on the flooded area percentage of Open Water. The center right column features a different subset, containing footprints with a negligible amount of Open Water $(<1 \%)$ and illustrates the relationship between the area percentage of flooded vegetation (Inundated Non-Forest and Inundated Forest) and DDM values. Lastly, the rightmost column is an even smaller subset of those footprints in the third 
column, consisting of those with negligible amounts of Inundated Non-Forest and Open Water $(<1 \%)$ and thereby isolating the relationship between the area of Inundated Forest and DDM measurements. The CYGNSS footprint data exhibited a high level of noise so were binned in equal intervals $(n=1000)$ by classified flood percentage in each plot.
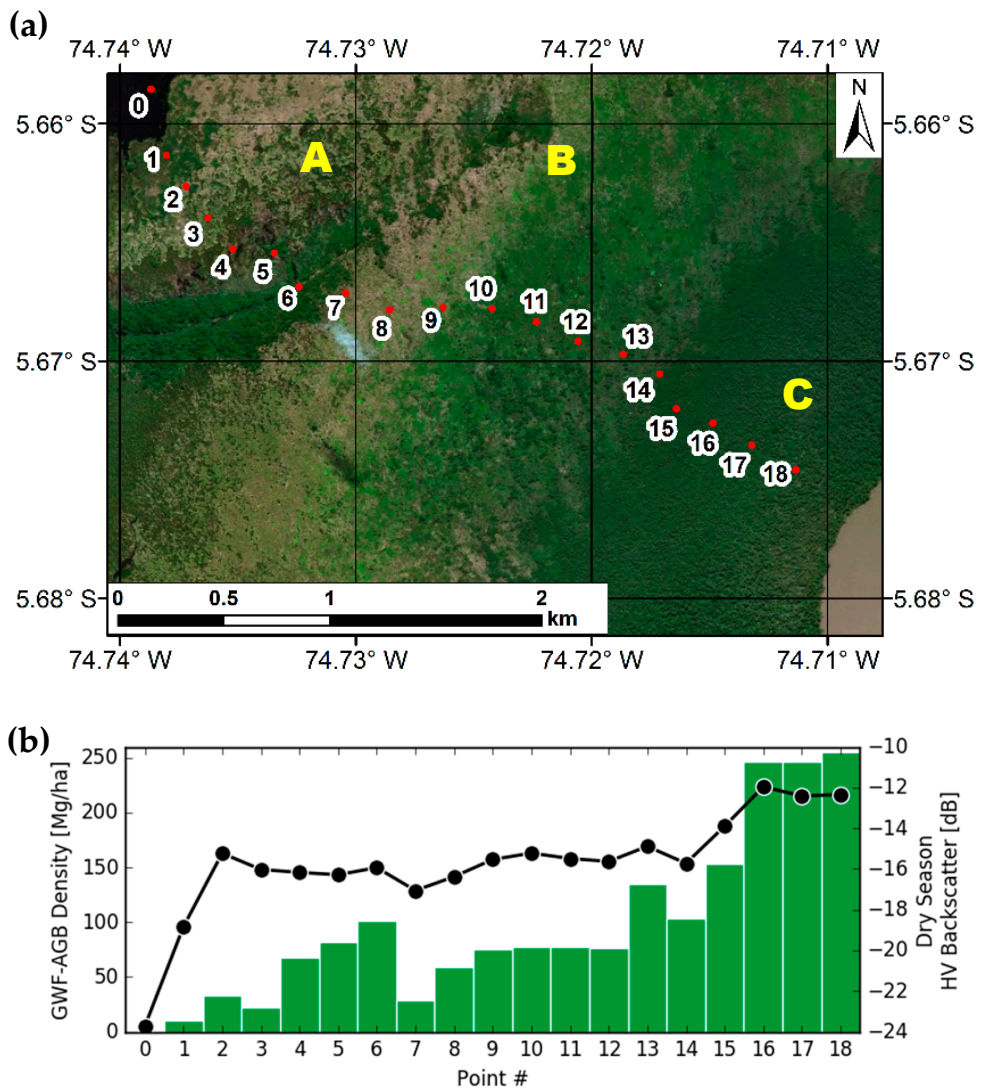

Figure 13. (a) Transect through inundated swamp; (b) GFW-derived AGB density (green bar, left axis) and HV-polarized PALSAR-2 ScanSAR backscatter (black line, right axis) for each point shown in transect. Three $0.01^{\circ} \times 0.01^{\circ}$ grid cells of interest are labelled A, B, C in yellow.

All DDM observations exhibited a generally logarithmic relationship with flooded area percentages regardless of vegetation conditions, with DDM SNR and LES increasing with greater flooded footprint area and TES decreasing with flooded area. SNR and TES observed greater goodness of fit with a logarithmic curve $\left(\mathrm{R}^{2}\right.$ ranging from 0.88 to 0.96$)$ than LES. TES appeared to exhibit greater variability than SNR at higher flooded area percentages. The GNSS-reflected signal approaches saturation at variable percentages of flooding, depending on vegetation cover and the type of observable. The SNR in particular appears to saturate at lower flooded percentages, showing near saturation at flooded area percentages as low as $20 \%$. The maximum value at which the DDM values saturated varied across the footprint subsets, illustrating the sensitivity of the GNSS-R signal to canopy attenuation. The largest ranges of binned DDM measurements are observed in the center left column which focuses on Open Water alone (SNR: 0 to 11 , LES: 0 to 1500 , TES: 0 to -70 ), and the narrowest range observed in the rightmost column focusing on Inundated Forest percentages alone (SNR: 0 to 4.5 , LES: 0 to 70 , TES: 0 to -3 ).

The influence of canopy attenuation was examined further by binning the DDM observations by overall flooded area percentage (Open Water, Inundated Non-Forest, Inundated Forest) in four distinct biomass density categories, as informed by the GFW-AGB dataset (Figure 15). The best-fit logarithmic curves derived from the lowest AGB density category $\left(<100 \mathrm{Mg} \mathrm{ha}^{-1}\right)$ observed the largest ranges in DDM values, with signal range decreasing as biomass density increases. The notable differences in the 
GNSS-R signatures with respect to flooded area percentage observed by these four biomass categories underscores the need for land cover information to interpret the GNSS-R signal.
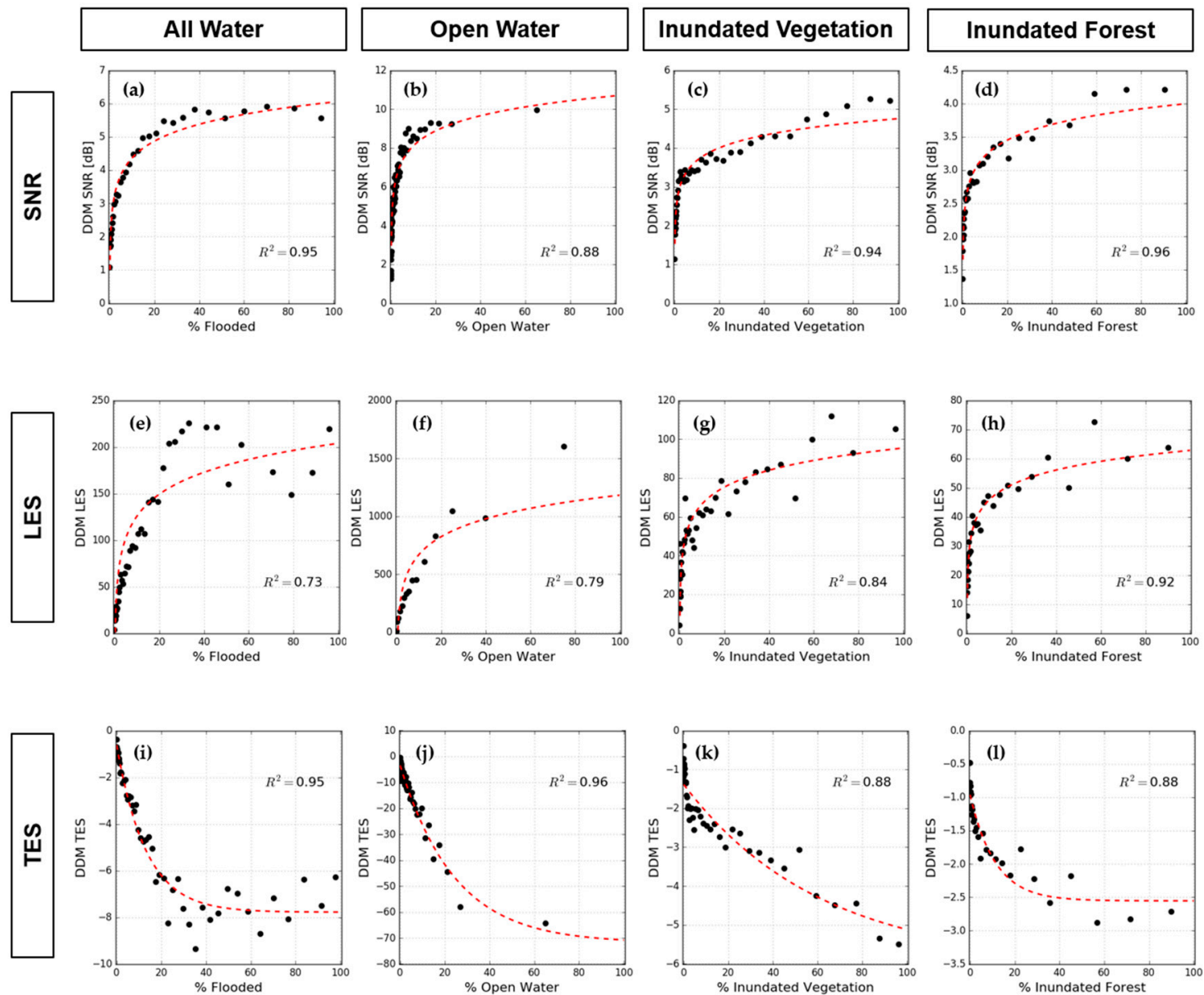

Figure 14. CYGNSS footprint flooded area percentage estimated with classified PALSAR-2 mosaics vs. CYGNSS DDM observations, including SNR in top row (a-d), LES in center row (e-h), and TES in bottom row (i-1). Leftmost column displays all footprints, where \% flooded counts flooded area regardless of vegetation (Open Water, Inundated Non-Forest, and Inundated Forest). The center left column presents the subset of the CYGNSS footprints with negligible inundated vegetation (Inundated Non-Forest and Inundated Forest of less than 5\%), focusing only on the percentage of Open Water in each footprint. The center right column displays the subset of footprints with negligible Open Water $(<1 \%)$ and displays the percentage of inundated vegetation (either Inundated Non-Forest or Inundated Forest). The rightmost column shows the subset of footprints with negligible Open Water or Inundated Non-Forest $(<1 \%)$ and displays the percentage of Inundated Forest. Median values of DDM values are displayed in black, derived from bins of equal size $(n=1000)$. 


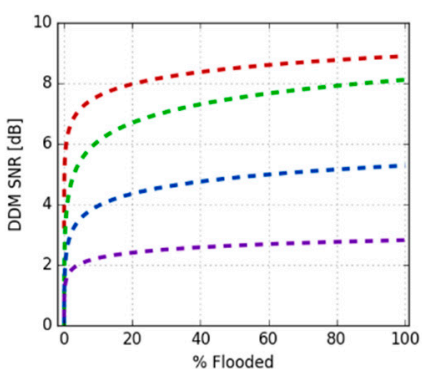

(a)

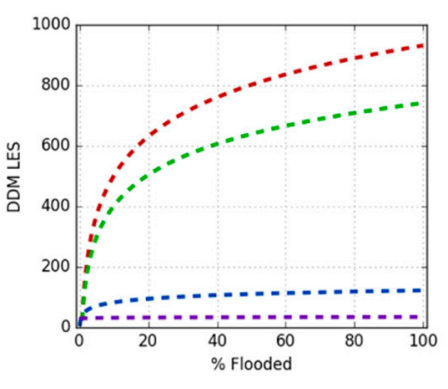

(b)

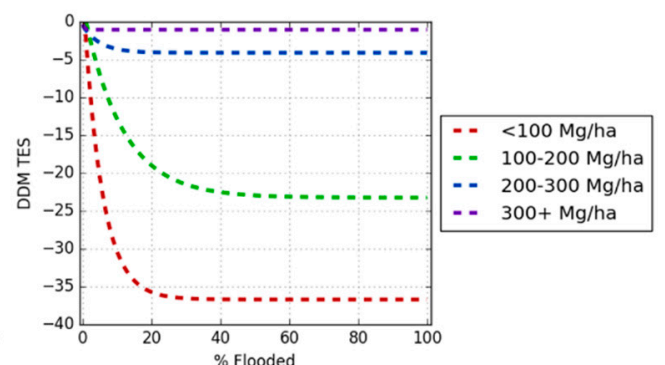

(c)

Figure 15. Relationship of footprint flooded area percentage (all flooded classes considered) vs. DDM (a) SNR; (b) LES; (c) TES. DDM observables are divided into four categories of GFW-AGB density $(<100$, 100-200, 200-300, and 300+ $\left.\mathrm{Mg} \mathrm{ha}^{-1}\right)$, with best-fit logarithmic curves shown in (a,b) and exponential fit used in (c).

\subsubsection{Comparison of SAR Classification and Peak DDM SNR at $1 \mathrm{~km}$ Scale}

Analysis of multi-temporal DDM observations are focused on SNR since it exhibits the least noise of the three observations examined. DDM SNR values are posted to a $0.01^{\circ}(\sim 1 \mathrm{~km})$ grid, with the time series maximum displayed over the study area in Figure 16a. The distribution of temporal maximum SNR in grid cells dominantly (>99\%) classified as a single maximum flooded extent class with the PALSAR-2 data shown in Figure 16b. The median peak SNR value observed in Open Water grid cells is highest, at $13.97 \mathrm{~dB}$, second highest in Inundated Non-Forest at $12.70 \mathrm{~dB}$, and third highest in Inundated Forest at $8.54 \mathrm{~dB}$, following the inverse relationship observed between peak SNR and amount of canopy attenuation above the flooded surface. The Non-Inundated class observed the lowest maximum SNR, with a median value among all dominantly Non-Inundated grid cells of 2.24 dB. There is a degree of overlap between the distributions of the Non-Inundated and all of the floodable classes, particularly between the top $75 \%$ of the Non-Inundated and the bottom $50 \%$ of the Inundated Forest, indicating that it may be difficult to differentiate flooded dense forest from non-inundated forest with GNSS-R signals alone. However, it also suggests there are potential regions of seasonally flooded vegetation that failed to be classified as flooded using the PALSAR-2 data but demonstrates increased DDM SNR that may be associated with surface inundation.

(a)

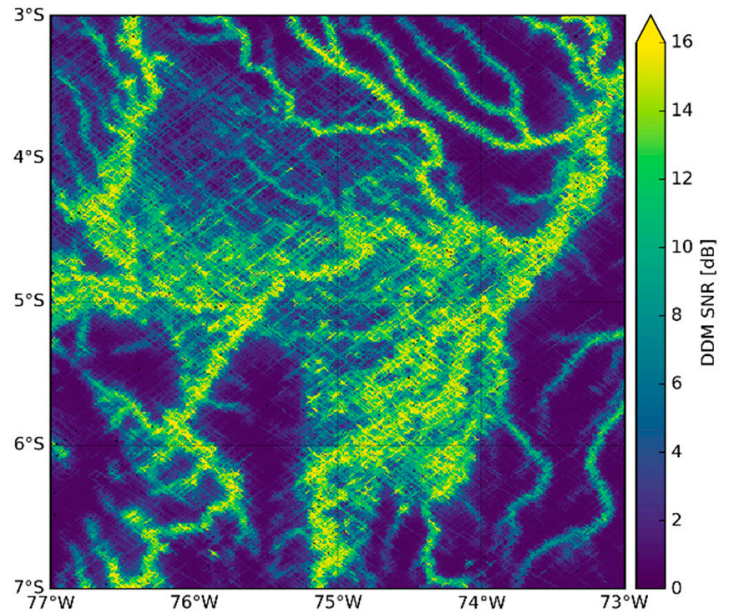

(b)

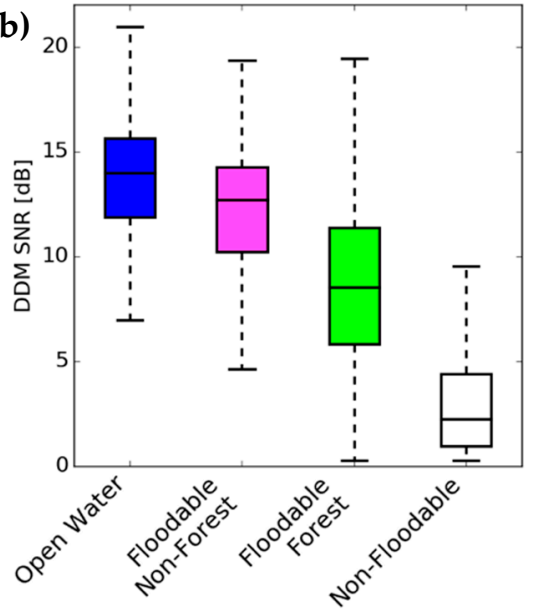

Figure 16. (a) Maximum CYGNSS DDM SNR observed between 18 March 2017-15 February 2018, posted at $0.01^{\circ}(\sim 1 \mathrm{~km})$ grid; (b) box plot delineating maximum DDM SNR grouped by PALSAR-2 maximum flooded extent class, including only $1 \mathrm{~km}$ pixels that are dominantly one class ( $\geq 99 \%)$. Central rectangle spans the first quartile to the third quartile (interquartile range), with median value illustrated as line inside the rectangle, and the minimum and maximum values indicated by the extent of the whiskers above and below the box. 


\subsubsection{Assessment with Ground Observations}

The classifications derived from the multi-temporal PALSAR-2 ScanSAR mosaics have allowed interpretation of the impact of vegetative cover on inundation detection with GNSS-R. However, as L-band SAR may have limited sensitivity to inundation dynamics under dense, high biomass forest canopies, PALSAR-2 does not provide an ideal validation dataset. Ground data collected along the line transects made in Pacaya Samiria were used to offer insight into the SAR-based classification errors. Seventy-eight out of 81 transect points showed clear evidence of seasonal flooding. Of these 78 points, 31 (39.7\%) are contained in pixels classified as "Non-Inundated" in the maximum flooded extent map derived from the PALSAR-2 ScanSAR mosaics. All three of the points that did not show evidence of past flooding were in pixels classified as Non-Inundated by the static PALSAR-based classification. Measured LAI and canopy cover of the 78 transect points (that showed evidence of past flooding) are illustrated in Figure 17a,b, along with the corresponding biomass density estimated by GFW-AGB shown in Figure 17c. In these boxplots, these vegetation structure metrics are grouped by the PALSAR-2 maximum flooded extent class. The 31 points where no flooding was ever detected by the PALSAR-2 classification time series but exhibited evidence of past inundation (shown in white) featured the highest values in all three vegetation metric categories (LAI, canopy cover, and AGB), further confirming the role of dense vegetation cover in under-classification of wetland area.

(a)

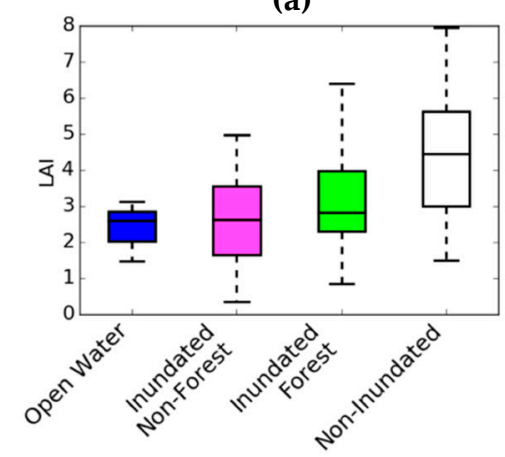

(b)

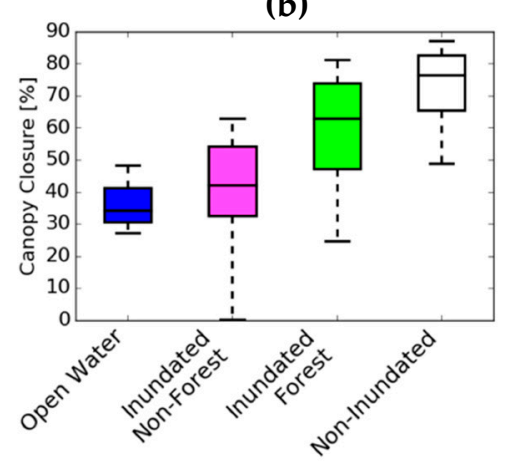

(c)

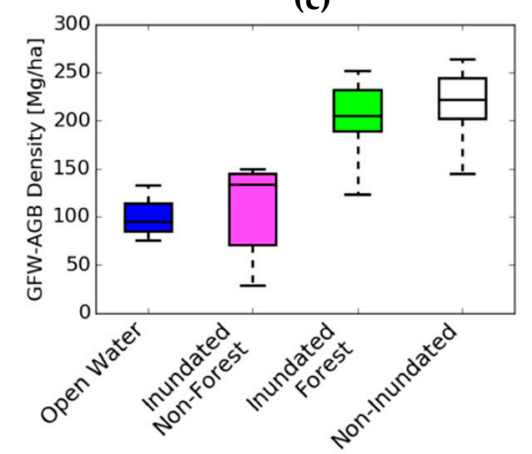

Figure 17. Distribution of vegetation structure metrics of transect points that showed evidence of seasonal flooding, grouped by PALSAR-2 maximum flooded extent class: (a) LAI; (b) canopy closure; (c) GFW-AGB density.

Another parameter to consider is maximum flood depth. Although it is expected that the height of the markings on trees left behind by past inundation events is generally representative of a past minimum inundation level, the depth observed by sustained inundation can be generally inferred from this value (although tree type can also have notable influence on this). Also, the presence of these inundation markings do not provide a direct indication of inundation timing, within or between years. The past inundation depths noted for the misclassified "Non-Inundated" transect points are markedly lower (median value of $0.5 \mathrm{~m}$ ) than those observed by the classified flooded classes (median value of $1.2 \mathrm{~m}$ ). A combination of dense canopy and comparatively shallow inundation depths may have contributed to under-classification of inundation in these areas by PALSAR-2.

Figure 18 illustrates a comparison of seasonal dynamics at four different $0.01^{\circ}(\sim 1 \mathrm{~km})$ grid cells with varying vegetative cover and inundation state. "Inundated Swamp I and II" and "Seasonally Inundated Forest" represent regions A, B, and C, respectively, from the large transect made through a swamp shown in Figure 13. "Terra Firme" represents an equivalently-sized grid cell identified in the non-inundated forest ROI K in Figure 4. As Figure 18a illustrates, a gradient of biomass density is observed across these four regions. All observed transect points in A and B were flooded during our visit in the dry season and are likely flooded throughout most of the year. However, $\mathrm{C}$ was observed to be partially non-inundated during the dry season but showed evidence of seasonal variation in inundation, as well as hosts much denser vegetation, and is thus referred to as "Seasonally Inundated 
Forest". The fourth region, referred to as "Terra Firme", represents an area known to rarely, if ever, flood and consists of high biomass density vegetation (GFW estimates ranging from 160-306 $\mathrm{Mg} \mathrm{ha}^{-1}$ ). Figure 18b,c illustrate the mean DDM SNR and PALSAR-2-derived flooded area percentage estimates observed during the high water (March, April, May) and low water (July, August, September) seasons of 2017 for each of the four regions. Inundated Swamp I and II both demonstrate high flood signals in both seasons, consistent with a perennially flooded swamp. A small decrease in DDM SNR and SAR-derived flooded percentage is observed in the low water season. Terra Firme, on the other hand, demonstrates a low flood signal in both datasets. The Seasonally Inundated Forest exhibited a lower DDM SNR and SAR-derived flooded area percentage than both Inundated Swamp areas, with a notable decrease in signal observed in the low water season by both datasets, likely corresponding with a seasonal retreat of inundation. The higher biomass density found in the Inundated Forest has presumably contributed to the overall lower flooded signal compared to the signals observed in the inundated swamps, but it is difficult to separate the influence of biomass and existent inundation. The Seasonally Inundated Forest DDM SNR signal appears to be higher than that of the SAR-derived flooded area percentages relative to the inundated swamps' measurements. This difference may be indicative of greater sensitivity to flooded vegetation by GNSS-R, but also may be due to the non-linear response of GNSS-R to the presence of surface water.

(a)

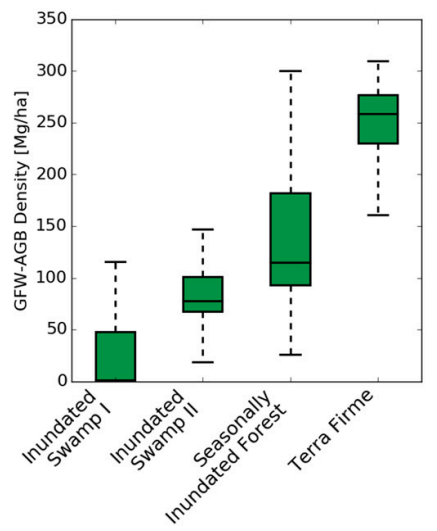

(b)

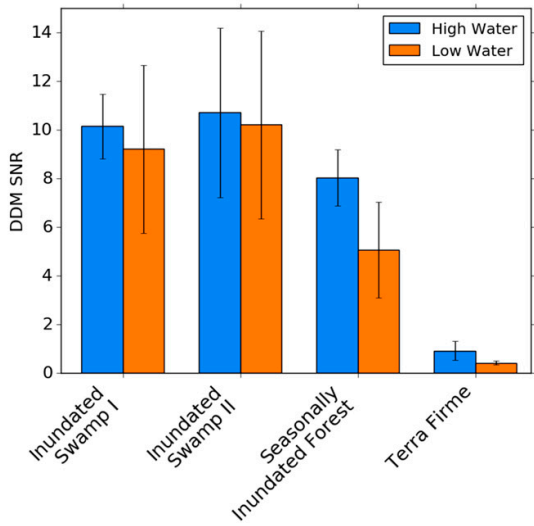

(c)

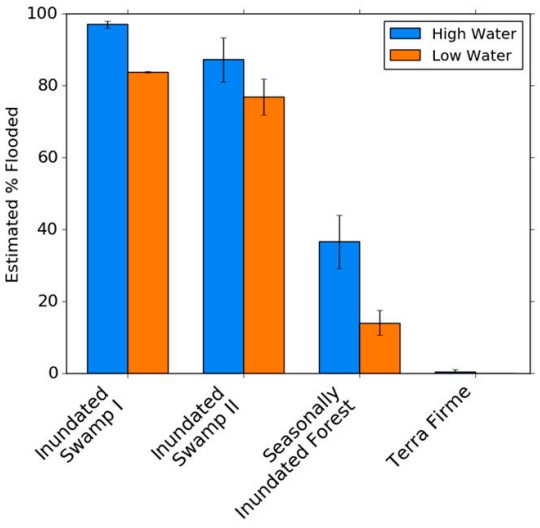

Figure 18. Comparison of high vs. low water seasons in 2017 at four $0.01^{\circ}$ grid cells. (a) Distribution of estimated GFW-AGB density observed in each grid cell; (b) observed CYGNSS DDM SNR during high vs. low water seasons in each region (number of observations ranged from 3-8 per season for each region); (c) estimated flooded area percentages derived from PALSAR-2 during high vs. low water seasons in each region (number of observations was 2 or 3 per season for each region). Bar charts $(\mathbf{b}, \mathbf{c})$ show mean values observed in seasonal window, with standard deviation indicated by error bars.

\section{Discussion}

\subsection{Backscatter vs. Forward-Scatter}

As demonstrated in numerous studies employing SAR over the past 30+ years, surface interactions between radar backscatter and inundated surfaces are generally well understood. Classification of L-band PALSAR-2 ScanSAR mosaics using established techniques were found to be generally very successful in detecting flooded surfaces, but did fail to detect inundation in several points in our ground data collection in transects of highly dense vegetation. One aspect not addressed in this study is the influence of the local incidence angle on backscatter. Because the SAR imagery used in this study was acquired using ScanSAR technology, the images cover a large swath width observed at a wide range of viewing angles $\left(\sim 18^{\circ}-70^{\circ}\right)$. The imaging angle influences the radar scattering physics and may in turn impact the land surface classification. In this study, PALSAR-2 data were provided pre-assembled as multi-temporal mosaics with little flexibility in image selection. Classification of 
these SAR images can be potentially improved with custom assembly of ScanSAR datasets, as was used by Reference [6], taking advantage of optimal viewing geometries supporting landcover classification.

GNSS-R, on the other hand, provides a new mapping approach. The potential of using reflected GNSS signals for studying terrestrial surface properties has been established, but the exploitation of such signals is still in its early stages. Our results have found that three aspects of the DDM (peak SNR, LES, and TES) are all sensitive to both inundation state and vegetative cover in a tropical wetlands complex, with SNR exhibiting the lowest noise of the three. The SNR signal approaches saturation at relatively low percentages of flooded area in a given footprint $(\sim 20 \%)$, which strongly supports the sensitivity to the presence of surface water but presents a challenge in quantifying the amount of surface water. The influence of canopy attenuation can be delineated using ancillary information on above-ground biomass. Derivation of DDM LES and TES relies on the estimated scattering area of each DDM and the estimated location of each DDM's specular point, which depends highly on signal calibration. The CYGNSS Science Team is still assessing GNSS-R calibration techniques over land, so an element of the uncertainty found in these current measurements may be improved with future updates to the CYGNSS L1 dataset [52]. The effects of incidence angle on these measurements have yet to be quantified and should be assessed in future work. Furthermore, in this study all surface reflections are assumed to be coherent over the wetland region. A calibration more accurately reflecting land cover composition would also account for contribution from the incoherent reflection. Radiometric modelling of reflected signals that allows assessment and interpretation of bistatic scattering physics should be conducted to further examine the degree of signal coherence in wetlands regions in addition to the influence of canopy attenuation. The role of biomass variability within a footprint on the DDM signal should also be explored in a modeling framework.

Validation of remote sensing-based, dynamic inundation datasets is immensely challenging due to a lack of large-scale in situ spatio-temporal information of inundation state. The very reason that makes these products so useful is what makes them so difficult to assess. Since CYGNSS footprints are much larger than imaging radar pixels, assessment of GNSS-R must rely on comparison of disparate remote sensing-based data at various spatial resolutions and with different temporal samplings. This study relied on generally successful, yet imperfect, classification of L-band SAR mosaics to assess GNSS-R. Comparison of SAR backscatter with the GNSS-R data at a radiometric level directly is problematic for complex wetland environments as radar backscatter can increase or decrease with inundation state depending on vegetation cover. Improvements can be made with access to greater amounts of ground information. Focused experiments that take advantage of controlled data acquisitions, such as one designed with aircraft instruments, combined with ground data collections and radiometric modeling, would limit sampling ambiguity and support direct comparison and assessment of SAR and GNSS-R technologies for mapping wetlands in complex environments.

\subsection{Potential for a Merged Approach}

Results from this study support the potential for a combined backscatter and forward-scatter approach to mapping wetlands that can leverage the combined benefits offered by SAR and GNSS-R. CYGNSS reflections resolved to a grid over wetland regions of interest can support estimates of the fractional coverage of open water and inundated vegetation at sub-weekly intervals (repeat time is inversely related to the grid size). Sub-grid cell information from contemporaneous SAR images can inform on vegetation cover and areas of open water and inundated vegetation, while reflected signals observed by CYGNSS can be used to estimate the total fraction of surface inundation, potentially using empirically- or radiometrically-derived relationships driven by biomass metrics. Such a technique may benefit from the improved capability of bistatic-scattered signal from GNSS-R by enhanced sensitivity to inundation under dense vegetation canopies.

Calculations of the temporal repeat frequency of CYGNSS data depend on the assumed footprint size. For example, the CYGNSS mission estimates that the mean revisit time over the ocean, where the

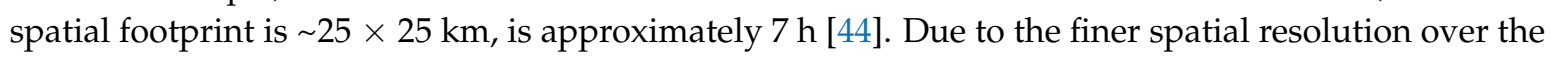


land surface, the temporal repeat time is longer. This study focused only on CYGNSS DDMs processed at the first Fresnel zone, but a larger footprint area can be achieved with greater understanding of the role of signal coherence on the DDM processing. The coarser the spatial grid in use, the greater the temporal coverage. For example, a grid cell of $\sim 9 \times 9 \mathrm{~km}$ in the tropics is sampled on average every $\sim 3$ days. Further examination is needed to focus on determining the optimal spatial resolution at which to resolve the reflected CYGNSS measurements for terrestrial applications.

\section{Conclusions}

This study documents the comparative capabilities of L-band SAR and GNSS-R for mapping tropical wetlands extent and inundation over a large tropical wetlands region with complex landcover. Dual-polarized multi-temporal L-band SAR mosaics provided by ALOS2 PALSAR-2 offer a rich time series (repeat time of 1-2 months) of interannual inundation dynamics in the Peruvian Amazon. Consistent with previous studies, ground measurements in areas of high biomass and canopy cover confirmed inundatable areas where inundation was not identified with SAR.

GNSS-R data from NASA's CYGNSS mission were analyzed in combination with the PALSAR-2-based wetlands assessments. Findings show that GNSS-R signals demonstrate a comparable sensitivity to the presence of surface water as standard techniques of classifying L-band SAR, with greater sensitivity possible but unconfirmed. A number of aspects of GNSS-R observations remain unanswered, including the roles of biomass variability and signal coherence on DDM observables.

One of the compelling characteristics of surface-reflected GNSS signals is their sensitivity to relatively high resolution $(\sim 1 \mathrm{~km})$ changes in inundation extent with potentially high temporal coverage. Harmonization of GNSS-R and L-band SAR has the potential for broader application to further the goal of quantifying wetlands extent and inundation patterns at pan-tropical scales. This offers an opportunity for research in time-sensitive hydrodynamic systems, such as assessing inter-annual variations in local flood pulse intensity, understanding water exchanges between floodplains and rivers, or validating estimates of carbon exchange in wetlands.

Author Contributions: Conceptualization: K.M., E.P. and N.S.; Formal analysis: K.J.; Funding acquisition: K.M. and E.P.; Investigation: K.J., K.M., E.P., V.H. and N.S.; Methodology: K.J., K.M., N.R.-A. and V.H.; Project administration: K.M. and E.P.; Resources: K.M. and V.H.; Software: K.J. and N.R.-A.; Supervision: K.M.; Visualization: K.J.; Writing—original draft: K.J.; Writing—review \& editing: K.M., N.R.-A., V.H. and N.S.

Funding: K.J. was supported by a graduate student fellowship from NASA Headquarters under the NASA Earth and Space Science Fellowship Program-Grant 80NSSC17K038. This research was supported by funding from the NASA Making Earth Science Data Records for Use in Research Environments (MEaSUREs) program under grant number NNX11AQ39G, and from the JPL Research Technology Development (RTD) program.

Acknowledgments: This research was undertaken in part within the framework of the ALOS Kyoto \& Carbon Initiative. PALSAR-2 data were provided by JAXA/EORC. The authors thank JAXA and Ake Rosenqvist for providing access to the multi-temporal ALOS2 PALSAR-2 ScanSAR mosaics. Access to the CYGNSS Level 1 version 2.1 data prior to public release was made possible thanks to the CYGNSS Science Team. Portions of this work were carried out at the Jet Propulsion Laboratory, California Institute of Technology, under contract with the National Aeronautics and Space Administration. (c) 2018. All rights reserved.

Conflicts of Interest: The authors declare no conflict of interest. 


\section{Appendix A. Additional Remote Sensing Dataset Information}

Table A1. ALOS2 PALSAR-2 ScanSAR mosaic observation date ranges for each cycle.

\begin{tabular}{|c|c|c|}
\hline Cycle \# & Start Date & End Date \\
\hline 10 & 24-November-2014 & 7-December-2014 \\
\hline 13 & 5-Janurary-2015 & 18-Januray-2015 \\
\hline 16 & 16-Feberary-2015 & 1-March-2015 \\
\hline 22 & 11-May-2015 & 24-May-2015 \\
\hline 25 & 22-June-2015 & 5-July-2015 \\
\hline 27 & 20-July-2015 & 2-Aug-2015 \\
\hline 30 & 31-August-2015 & 13-Septmember-2015 \\
\hline 33 & 12-October-2015 & 25-October-2015 \\
\hline 36 & 23-November-2015 & 6-December-2015 \\
\hline 39 & 4-Janurary-2016 & 17-Januray-2016 \\
\hline 42 & 15-Feberary-2016 & 28-Feberary-2016 \\
\hline 45 & 28-March-2016 & 10-April-2016 \\
\hline 48 & 9-May-2016 & 22-May-2016 \\
\hline 51 & 20-June-2016 & 3-July-2016 \\
\hline 53 & 18-July-2016 & 31-July-2016 \\
\hline 56 & 29-August-2016 & 11-Septemnber-2016 \\
\hline 59 & 10-October-2016 & 23-October-2016 \\
\hline 62 & 21-November-2016 & 4-December-2016 \\
\hline 65 & 2-Janurary-2017 & 15-Januray-2017 \\
\hline 68 & 13-Feberary-2017 & 26-Feberary-2017 \\
\hline 71 & 27-March-2017 & 9-April-2017 \\
\hline 74 & 8-May-2017 & 21-May-2017 \\
\hline 77 & 19-June-2017 & 2-July-2017 \\
\hline 79 & 17-July-2017 & 30-July-2017 \\
\hline 82 & 28-August-2017 & 10-September-2017 \\
\hline 85 & 9-Octomber-2017 & 22-October-2017 \\
\hline 88 & 20-November-2017 & 03-December-2017 \\
\hline 91 & 1-Janurary-2018 & 14-Janurary-2018 \\
\hline 93 & 29-Janurary-2018 & 11-February-2018 \\
\hline
\end{tabular}

Table A2. CYGNSS L1 data quality flags used in this study.

\begin{tabular}{cc}
\hline Quality Flag & Flagged in Analysis \\
\hline Poor Overall Quality & No \\
S Band Powered Up & Yes \\
Small Spacecraft Attitude Error & No \\
Large Spacecraft Attitude Error & Yes \\
Blackbody DDM & Yes \\
DDMI Reconfigured & Yes \\
Spacewire CRC Invalid & Yes \\
DDM is Test Patten & Yes \\
Channel Idle & Yes \\
Low Confidence DDM Noise Floor & No \\
SP Over Land & No \\
SP Very Near Land & No \\
SP Near Land & No \\
Large Step Noise Floor & No \\
Direct Signal in DDM & Yes \\
Low Confidence GPS EIRP Estimate & Yes \\
RFI Detected & Yes \\
BRCS DDM SP Bin Delay Error & No \\
BRCS DDM SP Bin Doppler Error & No \\
Negative BRCS Value Used for NRBCS & No \\
GPS PVT SP3 Error & No \\
SP Non Existent Error & Yes \\
BRCS LUT Range Error & No \\
Antenna Data LUT Range Error & No \\
Blackbody Framing Error & Yes \\
\hline
\end{tabular}




\section{Appendix B. Additional Details on Land Cover Classification Evaluation with Pacaya Samiria National Reserve map from IIAP}

Table A3. Description of IIAP land cover classes and the corresponding class used for evaluation.

\begin{tabular}{|c|c|c|}
\hline $\begin{array}{l}\text { Generalized Maximum } \\
\text { Flooded Extent Class }\end{array}$ & IIAP Class & Additional Description \\
\hline \multirow{2}{*}{ Inundated Non-Forest } & Herbaceous Swamp & $\begin{array}{l}\text { Floating plant species and other herbaceous plants } \\
\text { rooted in the soil; shrub species }<1.50 \mathrm{~m} \text { in height. } \\
\text { Typically inundated all year. }\end{array}$ \\
\hline & Arboreal Marsh & $\begin{array}{l}\text { Adjacent to the herbaceous/shrubby swamps that } \\
\text { have a higher frequency of tall plants such as } \\
\text { palms and trees; exposed to periodic flooding. }\end{array}$ \\
\hline \multirow{3}{*}{ Inundated Forest } & Palm Swamp & $\begin{array}{l}\text { Forest characterized by the dominance of the } \\
\text { species Mauritia flexuosa (aguaje/palm), exposed to } \\
\text { periodic flooding. }\end{array}$ \\
\hline & Meandering Forest & $\begin{array}{l}\text { Forests concentrated higher on river banks, with } \\
\text { plant communities of pioneer and colonizing } \\
\text { species, which are generally herbaceous and short } \\
\text { vegetative cycles; exposed to periodic flooding. }\end{array}$ \\
\hline & Low Floodplain Forest & $\begin{array}{l}\text { Forests consisting of communities more at a mature } \\
\text { stage of succession, presenting a more developed } \\
\text { canopy with trees that can reach more than } 25 \mathrm{~m} \text { in } \\
\text { height; exposed to periodic flooding. }\end{array}$ \\
\hline \multirow{2}{*}{ Non-Inundated } & Forest of Moderate Terrain & $\begin{array}{l}\text { Tree cover on terrain not exposed to periodic } \\
\text { flooding, supporting well developed trees that can } \\
\text { reach }>40 \mathrm{~m} \text { in height and } 1 \mathrm{~m} \text { in diameter }\end{array}$ \\
\hline & Forest of Low Hills & $\begin{array}{l}\text { Tree cover on terrain not exposed to periodic } \\
\text { flooding, developed on hillier terrain. }\end{array}$ \\
\hline
\end{tabular}

\section{Appendix C. Details on Indirect LAI Measurements}

The LAI 2200C Plant Canopy Analyzer is a portable instrument designed to measure diffuse light from several zenith angles. The sensor head is comprised of a "fish-eye" lens that focuses an image of the canopy on a silicon sensor having five detecting rings centered on the angles: $7^{\circ}, 23^{\circ}, 38^{\circ}, 53^{\circ}$, and $68^{\circ}$. Reference measurements make it possible to estimate for each ring a gap fraction computed as the ratio of light levels measured above and below the canopy. Four values were recorded in each plot quadrant, corresponding to the four cardinal directions, yielding 16 total LAI measurements per plot. The wand was leveled and held below the understory at a height of approximately $1.5 \mathrm{~m}$ from the ground. A $270^{\circ}$ view cap was used to eliminate the image of the experimenter. Reference measurements were continuously recorded with a second wand in a clearing which was large enough to provide a reliable reference for all five rings. 


\section{Appendix D. Ground Reference Measurements}

Table A4. Summary of circular plot characteristics.

\begin{tabular}{|c|c|c|c|c|c|c|c|c|}
\hline \multirow{2}{*}{\multicolumn{2}{|c|}{ Attribute }} & \multicolumn{7}{|c|}{ Circular Plot \# } \\
\hline & & \multirow{2}{*}{$\begin{array}{l}\text { S1C1 } \\
11.27\end{array}$} & \multirow{2}{*}{$\begin{array}{l}\text { S1C2 } \\
12.87\end{array}$} & \multirow{2}{*}{$\begin{array}{c}\text { S2C1 } \\
8.15\end{array}$} & \multirow{2}{*}{$\begin{array}{l}\text { S2C2 } \\
12.89\end{array}$} & \multirow{2}{*}{$\begin{array}{l}\text { S3C1 } \\
12.99\end{array}$} & \multirow{2}{*}{$\begin{array}{l}\text { S3C2 } \\
18.12\end{array}$} & \multirow{2}{*}{$\begin{array}{c}\text { S4C1 } \\
9.82\end{array}$} \\
\hline Tree Height & Mean & & & & & & & \\
\hline$[\mathrm{m}]$ & Stdev & 4.00 & 5.86 & 3.66 & 5.26 & 7.18 & 7.50 & 2.95 \\
\hline \multirow{2}{*}{$\begin{array}{c}\text { Crown Depth } \\
{[\mathrm{m}]}\end{array}$} & Mean & 4.21 & 5.24 & 3.36 & 3.73 & 5.19 & 7.96 & 4.18 \\
\hline & Stdev & 2.36 & 3.66 & 2.34 & 2.21 & 3.29 & 6.15 & 2.31 \\
\hline \multirow{2}{*}{$\mathrm{DBH}[\mathrm{cm}]$} & Mean & 27.61 & 18.51 & 14.05 & 17.34 & 17.53 & 15.54 & 13.57 \\
\hline & Stdev & 12.17 & 15.29 & 11.84 & 12.97 & 13.14 & 9.20 & 7.15 \\
\hline \multicolumn{2}{|c|}{ Understory Height [m] } & 1.50 & 3.90 & - & 3.80 & 1.74 & 3.39 & - \\
\hline \multicolumn{2}{|c|}{ Tree Basal Area $\left[\mathrm{m}^{2} \mathrm{ha}^{-1}\right]$} & 22.09 & 45.14 & 25.48 & 37.57 & 20.60 & 31.07 & 14.05 \\
\hline \multicolumn{2}{|c|}{ Canopy Closure [\%] } & 43.06 & 82.84 & 59.12 & 79.66 & 83.82 & 83.69 & 75.82 \\
\hline \multicolumn{2}{|c|}{ Leaf Area Index $\left[\mathrm{m}^{2} \mathrm{~m}^{-2}\right]$} & 1.46 & 4.89 & 2.91 & 5.20 & 5.62 & 5.23 & 3.06 \\
\hline \multicolumn{2}{|c|}{ AGB Density $\left[\mathrm{Mg} \mathrm{ha}^{-1}\right]$} & 61.61 & 278.31 & 68.93 & 151.80 & 141.40 & 191.75 & 42.21 \\
\hline \multicolumn{2}{|c|}{ Past Flood Depth [m] } & 1.95 & 0.75 & 1.30 & 0.63 & 0.25 & 0.30 & 0.68 \\
\hline
\end{tabular}

Table A5. Line transect descriptive statistics.

\begin{tabular}{cccccccc}
\hline \multirow{2}{*}{ Attribute } & & \multicolumn{7}{c}{ Transect \# } & \\
\cline { 3 - 8 } & & S1TA & S1TB & S2TA & S2TB & S3TA & S4TA \\
\hline \multirow{2}{*}{ \# Points Along Transect } & & 9 & 14 & 25 & 7 & 15 & 11 \\
\hline \multirow{2}{*}{ Tree Height [m] } & Mean & 14.97 & 14.53 & 20.21 & 22.79 & 18.17 & 10.18 \\
& Stdev & 7.44 & 2.80 & 7.43 & 17.75 & 4.55 & 2.35 \\
\hline \multirow{2}{*}{ Crown Depth [m] } & Mean & 6.19 & 5.72 & 8.22 & 6.19 & 8.41 & 5.46 \\
& Stdev & 4.55 & 2.29 & 4.26 & 6.05 & 3.41 & 1.77 \\
\hline \multirow{2}{*}{ Understory Height [m] } & Mean & 1.68 & 1.61 & 6.96 & 8.79 & 4.73 & 2.93 \\
& Stdev & 0.91 & 0.72 & 2.97 & 3.91 & 0.92 & 0.98 \\
\hline \multirow{2}{*}{ Canopy Closure [\%] } & Mean & 45.95 & 54.02 & 58.21 & 79.79 & 78.54 & 55.87 \\
& Stdev & 23.28 & 18.86 & 15.93 & 5.30 & 8.70 & 13.94 \\
\hline \multirow{2}{*}{ Leaf Area Index [m $\left.{ }^{2} \mathrm{~m}{ }^{-2}\right]$} & Mean & 2.76 & 4.22 & 2.48 & 4.78 & 5.80 & 2.53 \\
& Stdev & 1.58 & 1.75 & 0.91 & 0.58 & 1.34 & 0.64 \\
\hline \multirow{2}{*}{ Past Inundation Depth [m] } & Mean & 1.79 & 1.58 & 0.54 & 0.66 & 0.50 & 1.20 \\
& Stdev & 0.42 & 0.36 & 0.22 & 0.72 & - & 0.13 \\
\hline
\end{tabular}

\section{References}

1. Castello, L.; McGrath, D.G.; Hess, L.L.; Coe, M.T.; Lefebvre, P.A.; Petry, P.; Macedo, M.N.; Renó, V.F.; Arantes, C.C. The vulnerability of Amazon freshwater ecosystems. Conserv. Lett. 2012, 6, 217-229. [CrossRef]

2. Richey, J.E.; Melack, J.M.; Aufdenkampe, A.K.; Ballester, V.M.; Hess, L.L. Outgassing from Amazonian rivers and wetlands as a large tropical source of atmospheric $\mathrm{CO}_{2}$. Nature 2002, 416, 617-620. [CrossRef] [PubMed]

3. Melton, J.R.; Wania, R.; Hodson, E.L.; Poulter, B.; Ringeval, B.; Spahni, R.; Bohn, T.; Avis, C.A.; Beerling, D.J.; Chen, G.; et al. Present state of global wetland extent and wetland methane modelling: Conclusions from a model intercomparison project (WETCHIMP). Biogeosciences 2013, 10, 753-788. [CrossRef]

4. Hess, L.L.; Melack, J.M.; Simonett, D.S. Radar detection of flooding beneath the forest canopy: A review. Int. J. Remote Sens. 1990, 11, 1313-1325. [CrossRef]

5. Hess, L.L.; Melack, J.M.; Filoso, S.; Wang, Y. Delineation of inundated area and vegetation along the Amazon floodplain with the SIR-C synthetic aperture radar. IEEE Trans. Geosci. Remote Sens. 1995, 33, 896-904. [CrossRef]

6. Chapman, B.; McDonald, K.; Shimada, M.; Rosenqvist, A.; Schroeder, R.; Hess, L. Mapping regional inundation with spaceborne L-band SAR. Remote Sens. 2015, 7, 5440-5470. [CrossRef] 
7. Kandus, P.; Minotti, P.G.; Morandeira, N.S.; Grimson, R.; Trilla, G.G.; González, E.B.; Martín, L.S.; Gayol, M.P. Remote sensing of wetlands in South America: Status and challenges. Int. J. Remote Sens. 2018, 39, 993-1016. [CrossRef]

8. Chapman, B.D.; Celi, J.E.; Hamilton, S.K.; McDonald, K.C. Detection and monitoring of inundation with polarimetric L-band SAR. In Proceedings of the 2014 AGU Fall Meeting, San Francisco, CA, USA, 15-19 December 2014.

9. Chapman, B.; Celi, J.; Hamilton, S.; McDonald, K. Validation of forested inundation extent revealed by L-band polarimetric and interferometric SAR data. In Proceedings of the 2014 IEEE International Geoscience and Remote Sensing Symposium, Quebec, QC, Canada, 13-18 July 2014.

10. Yuan, T.; Lee, H.; Jung, H.C. Toward estimating wetland water level changes based on hydrological sensitivity analysis of PALSAR backscattering coefficients over different vegetation fields. Remote Sens. 2015, 7, 3153-3183. [CrossRef]

11. Martin-Neira, M. A passive reflectometry and interferometry system (PARIS): Application to ocean altimetry. ESA J.-Eur. Space Agency 1993, 17, 331-355.

12. Garrison, J.L.; Katzberg, S.J.; Hill, M.I. Effect of sea roughness on bistatically scattered range coded signals from the Global Positioning System. Geophys. Res. Lett. 1998, 25, 2257-2260. [CrossRef]

13. Zavorotny, V.U.; Voronovich, A.G. Bistatic GPS signal reflections at various polarizations from rough land surface with moisture content. In Proceedings of the 2000 IEEE International Geoscience and Remote Sensing Symposium, Honolulu, HI, USA, 24-28 July 2000; pp. 2852-2854. [CrossRef]

14. Rodriguez-Alvarez, N.; Camps, A.; Vall-llossera, M.; Bosch-Lluis, X.; Monerris, A.; Ramos-Perez, I.; Valencia, E.; Marchan-Hernandez, J.F.; Martinez-Fernandez, J.; Baroncini-Turricchia, G.; et al. Land geophysical parameters retrieval using the interference pattern GNSS-R technique. IEEE Trans. Geosci. Remote Sens. 2011, 49, 71-84. [CrossRef]

15. Egido, A.; Caparrini, M.; Ruffini, G.; Paloscia, S.; Santi, E.; Guerriero, L.; Pierdicca, N.; Floury, N. Global navigation satellite systems reflectometry as a remote sensing tool for agriculture. Remote Sens. 2012, 4, 2356-2372. [CrossRef]

16. Beckheinrich, J.; Beyerle, G.; Schoen, S.; Apel, H.; Semmling, M.; Wickert, J. WISDOM: GNSS-R based flood monitoring. In Proceedings of the 2012 Workshop on Reflectometry Using GNSS and Other Signals of Opportunity (GNSS+R), West Lafayette, IN, USA, 10-11 October 2012; pp. 1-6. [CrossRef]

17. Chew, C.; Reager, J.T.; Small, E. CYGNSS data map flood inundation during the 2017 Atlantic hurricane season. Sci. Rep 2018, 8, 9336. [CrossRef] [PubMed]

18. Larson, K.M.; Gutmann, E.D.; Zavorotny, V.U.; Braun, J.J.; Williams, M.W.; Nievinski, F.G. Can we measure snow depth with GPS receivers? Geophys. Res. Lett. 2009, 36, L17502. [CrossRef]

19. Cardellach, E.; Fabra, F.; Rius, A.; Pettinato, S.; D'Addio, S. Characterization of dry-snow sub-structure using GNSS reflected signals. Remote Sens. Environ. 2012, 124, 122-134. [CrossRef]

20. Rodriguez-Alvarez, N.; Bosch-Lluis, X.; Camps, A.; Vall-llossera, M.; Valencia, E.; Marchan-Hernandez, J.F.; Ramos-Perez, I. Soil moisture retrieval using GNSS-R techniques: Experimental results over a bare soil field. IEEE Trans. Geosci. Remote Sens. 2009, 47, 3616-3624. [CrossRef]

21. Roussel, N.; Frappart, F.; Ramillien, G.; Darrozes, J.; Baup, F.; Ha, C. Detection of soil moisture content changes by using a single geodetic antenna: The case of an agricultural plot. In Proceedings of the 2015 IEEE International Geoscience and Remote Sensing Symposium, Milan, Italy, 26-31 July 2015; pp. 2008-2011. [CrossRef]

22. Egido, A.; Paloscia, S.; Motte, E.; Guerriero, L.; Pierdicca, N.; Caparrini, M.; Santi, E.; Fontanelli, G.; Floury, N. Airborne GNSS-R polarimetric measurements for soil moisture and above-ground biomass estimation. IEEE J. Sel. Top. Appl. 2014, 7, 1522-1532. [CrossRef]

23. Camps, A.; Park, H.; Pablos, M.; Foti, G.; Gommenginger, C.P.; Liu, P.W.; Judge, J. Sensitivity of GNSS-R spaceborne observations to soil moisture and vegetation. IEEE J. Sel. Top. Appl. 2016, 9, 4730-4742. [CrossRef]

24. Motte, E.; Zribi, M.; Fanise, P.; Egido, A.; Darrozes, J.; Al-Yaari, A.; Baghdadi, N.; Baup, F.; Dayau, S.; Fieuzal, R.; et al. GLORI: A GNSS-R dual polarization airborne instrument for land surface monitoring. Sensors 2016, 16, 732. [CrossRef] [PubMed]

25. Chew, C.; Shah, R.; Zuffada, C.; Hajj, G.; Masters, D.; Mannucci, A.J. Demonstrating soil moisture remote sensing with observations from the UK TechDemoSat-1 satellite mission. Geophys. Res. Lett. 2016, 43, 3317-3324. [CrossRef] 
26. Zavorotny, V.U.; Larson, K.M.; Braun, J.J.; Small, E.E.; Gutmann, E.D.; Bilich, A.L. A physical model for GPS multipath caused by land reflections: Toward bare soil moisture retrievals. IEEE J. Sel. Top. Appl. 2010, 3, 100-110. [CrossRef]

27. Guerriero, L.; Pierdicca, N.; Egido, A.; Caparrini, M.; Paloscia, S.; Santi, E.; Floury, N. Modeling of the GNSS-R signal as a function of soil moisture and vegetation biomass. In Proceedings of the 2013 IEEE International Geoscience and Remote Sensing Symposium, Melbourne, Australia, 21-26 July 2013; pp. 4050-4053. [CrossRef]

28. Wu, X.; Jin, S. GNSS-Reflectometry: Forest canopies polarization scattering properties and modeling. Adv. Space Res. 2014, 54, 863-870. [CrossRef]

29. Zavorotny, V.U.; Gleason, S.; Cardellach, E.; Camps, A. Tutorial on Remote Sensing Using GNSS Bistatic Radar of Opportunity. IEEE Geosci. Remote Sens. Mag. 2014, 2, 8-45. [CrossRef]

30. Nghiem, S.V.; Zuffada, C.; Shah, R.; Chew, C.; Lowe, S.T.; Mannucci, A.J.; Cardellach, E.; Brakenridge, G.R.; Geller, G.; Rosenqvist, A. Wetland monitoring with Global Navigation Satellite System reflectometry. Earth Space Sci. 2016, 4, 16-39. [CrossRef] [PubMed]

31. Hess, L.L.; Melack, J.M.; Affonso, A.G.; Barbosa, C.C.F.; Gastil-Buhl, M.; Novo, E.M.L.M. Wetlands of the lowland Amazon basin: Extent, vegetative cover, and dual-season inundated area as mapped with JERS-1 synthetic aperture radar. Wetlands 2015, 35, 745-756. [CrossRef]

32. Seyler, F.; Muller, F.; Cochonneau, G.; Guimarães, L.; Guyot, J.L. Watershed delineation for the Amazon sub-basin system using GTOPO30 DEM and a drainage network extracted from JERS SAR images. Hydrol. Process. 2009, 23, 3173-3185. [CrossRef]

33. SENAMHI. Available online: https://www.senamhi.gob.pe/ (accessed on 2 June 2018).

34. Rosenqvist, A.; Shimada, M.; Suzuki, S.; Ohgushi, F.; Tadono, T.; Watanabe, M.; Tsuzuku, K.; Watanabe, T.; Kamijo, S.; Aoki, E. Operational performance of the ALOS global systematic acquisition strategy and observation plans for ALOS-2 PALSAR-2. Remote Sens. Environ. 2014, 155, 3-12. [CrossRef]

35. Shimada, M.; Isoguchi, O.; Tadono, T.; Isono, K. PALSAR radiometric and geometric calibration. IEEE Trans. Geosci. Remote Sens. 2009, 47, 3915-3932. [CrossRef]

36. Arnesen, A.S.; Silva, T.S.F.; Hess, L.L.; Novo, E.M.L.M.; Rudorff, C.M.; Chapman, B.D.; McDonald, K.C. Monitoring flood extent in the lower Amazon River floodplain using ALOS/PALSAR ScanSAR images. Remote Sens. Environ. 2013, 130, 51-61. [CrossRef]

37. Fluet-Chouinard, E.; Lehner, B.; Rebelo, L.M.; Papa, F.; Hamilton, S.K. Development of a global inundation map at high spatial resolution from topographic downscaling of coarse-scale remote sensing data. Remote Sens. Environ. 2015, 158, 348-361. [CrossRef]

38. Schlaffer, S.; Chini, M.; Dettmering, D.; Wagner, W. Mapping wetlands in Zambia using seasonal backscatter signatures derived from ENVISAT ASAR time series. Remote Sens. 2016, 8, 402. [CrossRef]

39. Rennó, C.D.; Nobre, A.D.; Cuartas, L.A.; Soares, J.V.; Hodnett, M.G.; Tomasella, J.; Waterloo, M.J. HAND, a new terrain descriptor using SRTM-DEM: Mapping terra-firme rainforest environments in Amazonia. Remote Sens. Environ. 2008, 112, 3469-3481. [CrossRef]

40. Nobre, A.D.; Cuartas, L.A.; Hodnett, M.; Rennó, C.D.; Rodrigues, G.; Silveira, A.; Waterloo, M.; Saleska, S. Height Above the Nearest Drainage-A hydrologically relevant new terrain model. J. Hydrol. 2011, 404, 13-29. [CrossRef]

41. Lehner, B.; Verdin, K.; Jarvis, A. New global hydrography derived from spaceborne elevation data. EOS Trans. Am. Geophys. Union 2008, 89, 93-94. [CrossRef]

42. Farr, T.G.; Rosen, P.A.; Caro, E.; Crippen, R.; Duren, R.; Hensley, S.; Kobrick, M.; Paller, M.; Rodriguez, E.; Roth, L.; et al. The Shuttle Radar Topography Mission. Rev. Geophys. 2007, 45. [CrossRef]

43. IIAP. Available online: http:/ / www.iiap.org.pe (accessed on 25 May 2018).

44. Ruf, C.S.; Atlas, R.; Chang, P.S.; Clarizia, M.P.; Garrison, J.L.; Gleason, S.; Katzberg, S.J.; Jelenak, Z.; Johnson, J.T.; Majumdar, S.J.; et al. New ocean winds satellite mission to probe hurricanes and tropical convection. Bull. Am. Meteorol. Soc. 2016, 97, 385-395. [CrossRef]

45. Rodriguez-Alvarez, N.; Podest, E.; Jensen, K.; McDonald, K. Monitoring surface inundation with CYGNSS. In Proceedings of the 2018 CYGNSS Science Team Meeting, Ann Arbor, MI, USA, 18-20 June 2018.

46. Hajj, G.A.; Zuffada, C. Theoretical description of a bistatic system for ocean altimetry using the GPS signal. Radio Sci. 2003, 38, 1089. [CrossRef] 
47. Chave, J.; Coomes, D.; Jansen, S.; Lewis, S.L.; Swenson, N.G.; Zanne, A.E. Towards a worldwide wood economics spectrum. Ecol. Lett. 2009, 12, 351-366. [CrossRef] [PubMed]

48. Zanne, A.E.; Lopez-Gonzalez, G.; Coomes, D.A.; Ilic, J.; Jansen, S.; Lewis, S.L.; Miller, R.B.; Swenson, N.G.; Wiemann, M.C.; Chave, J. Dryad Digital Repository. Available online: https:/ / doi.org/10.5061/dryad.234 (accessed on 22 May 2018).

49. Chave, J.; Réjou-Méchain, M.; Búrquez, A.; Chidumayo, E.; Colgan, M.S.; Delitti, W.B.C.; Duque, A.; Eid, T.; Fearnside, P.M.; Goodman, R.C.; et al. Improved allometric models to estimate the aboveground biomass of tropical trees. Glob. Chang. Biol. 2014, 20, 3177-3190. [CrossRef] [PubMed]

50. Global Forest Watch. Aboveground Live Woody Biomass Density. Available online: http://data. globalforestwatch.org/datasets/aboveground-live-woody-biomass-density (accessed on 9 March 2018).

51. Martinez, J.-M.; Le Toan, T. Mapping of flood dynamics and spatial distribution of vegetation in the Amazon floodplain using multitemporal SAR data. Remote Sens. Environ. 2007, 108, 209-223. [CrossRef]

52. Saïd, F.; Jelenak, Z.; Chang, P.S.; Soisuvarn, S. An assessment of CYGNSS normalized bistatic radar cross section calibration. IEEE J. Sel. Top. Appl. 2018, 1-16. [CrossRef]

(C) 2018 by the authors. Licensee MDPI, Basel, Switzerland. This article is an open access article distributed under the terms and conditions of the Creative Commons Attribution (CC BY) license (http://creativecommons.org/licenses/by/4.0/). 